\title{
Potassium: A Vital Regulator of Plant Responses and Tolerance to Abiotic Stresses
}

\author{
Mirza Hasanuzzaman 1,*, M. H. M. Borhannuddin Bhuyan 2,3 (1D, Kamrun Nahar ${ }^{4}$, \\ Md. Shahadat Hossain ${ }^{2}$, Jubayer Al Mahmud ${ }^{5}$, Md. Shahadat Hossen ${ }^{1}$, \\ Abdul Awal Chowdhury Masud ${ }^{1}$ (D), Moumita ${ }^{1}$ and Masayuki Fujita ${ }^{2, *}$ \\ 1 Department of Agronomy, Faculty of Agriculture, Sher-e-Bangla Agricultural University, Dhaka 1207, \\ Bangladesh; shahadat.hossen32@yahoo.com (M.S.H.); chy.masud3844@gmail.com (A.A.C.M.); \\ moumita1ly@gmail.com (M.) \\ 2 Laboratory of Plant Stress Responses, Faculty of Agriculture, Kagawa University, Miki-cho, \\ Kagawa 761-0795, Japan; razon_sau@yahoo.com (M.H.M.B.B.); shahadatsau24@gmail.com (M.S.H.) \\ 3 Bangladesh Agricultural Research Institute, Joydebpur, Gazipur 1701, Bangladesh \\ 4 Department of Agricultural Botany, Faculty of Agriculture, Sher-e-Bangla Agricultural University, \\ Dhaka 1207, Bangladesh; knahar84@yahoo.com \\ 5 Department of Agroforestry and Environmental Science, Faculty of Agriculture, Sher-e-Bangla Agricultural \\ University, Dhaka 1207, Bangladesh; jamahmud_bd@yahoo.com \\ * $\quad$ Correspondence: mhzsauag@yahoo.com (M.H.); fujita@ag.kagawa-u.ac.jp (M.F.); Tel.: +81-87-891-3033 (M.F.)
}

Received: 23 January 2018; Accepted: 10 March 2018; Published: 12 March 2018

\begin{abstract}
Among the plant nutrients, potassium (K) is one of the vital elements required for plant growth and physiology. Potassium is not only a constituent of the plant structure but it also has a regulatory function in several biochemical processes related to protein synthesis, carbohydrate metabolism, and enzyme activation. Several physiological processes depend on $\mathrm{K}$, such as stomatal regulation and photosynthesis. In recent decades, $\mathrm{K}$ was found to provide abiotic stress tolerance. Under salt stress, $\mathrm{K}$ helps to maintain ion homeostasis and to regulate the osmotic balance. Under drought stress conditions, K regulates stomatal opening and helps plants adapt to water deficits. Many reports support the notion that $\mathrm{K}$ enhances antioxidant defense in plants and therefore protects them from oxidative stress under various environmental adversities. In addition, this element provides some cellular signaling alone or in association with other signaling molecules and phytohormones. Although considerable progress has been made in understanding K-induced abiotic stress tolerance in plants, the exact molecular mechanisms of these protections are still under investigation. In this review, we summarized the recent literature on the biological functions of $\mathrm{K}$, its uptake, its translocation, and its role in plant abiotic stress tolerance.
\end{abstract}

Keywords: abiotic stress; antioxidant defense; enzyme regulations; oxidative stress; plant nutrients; reactive oxygen species; soil fertility

\section{Introduction}

Most cultivable crops experience one or more abiotic stress(es) of some type throughout their growth stages. Thus, increasing plant resilience in response to abiotic stress is a great challenge in the effort to improve food production by $70 \%$ to feed the increasing population by the year 2050 [1]. Abiotic stress hampers plant productivity by altering plant growth patterns and physiological responses [2,3]. The combination of different stresses that affect crops has become more common; for example, the occurrence of drought and high temperature is the most common [4], while in arid and semi-arid regions, salinity and high temperature stresses are imposed at the same time. High light and high temperature stress, drought and salinity, or high temperature, occur simultaneously under current 
conditions. Due to the complex nature of this stress, plants are more adversely affected, and hence, research on plant stress tolerance is constantly changing and being updated with the new forms of stresses [1,3]. These complex stresses cause changes in cropping patterns, crop cultural practices, and sometimes, the extinction of plant species. Since the beginning of agriculture, a range of cultural practices has been developed through continuous trial and error processes. Among the cultivation practices, the use of fertilizers and organic amendments are the oldest methods for improving plant productivity. However, as a chemical fertilizer, potassium $(\mathrm{K})$ has been used on crop field since the nineteenth century [5].

The role of $\mathrm{K}$ in the plant developmental process is well known. The upregulation of the $\mathrm{K}$ status decreases reactive oxygen species (ROS) generation in plants. Potassium reduces the activity of nicotinamide adenine dinucleotide phosphate (NADPH) oxidases and retains the photosynthetic electron transport activity, which helps to reduce ROS. Potassium deficiencies can decrease the photosynthetic $\mathrm{CO}_{2}$ fixation and the transport and utilization of assimilates [6]. Membrane and chlorophyll (chl) degradation are favored in K-deficient plants. The regulation of $\mathrm{K}$ is associated with the activity of the enzymes involved in ROS detoxification [5]. Potassium triggers the activation of the adenosine triphosphate (ATP) synthase enzyme. The plasma membrane-bound $\mathrm{H}^{+}$-ATPase is influenced by the $\mathrm{K}$ content [7]. Potassium-deficient plants have been reported to be light-sensitive, and thus they exhibit chlorotic and necrotic symptoms [5]. Potassium was reported to decrease different stress effects in plants such as drought, chilling, and high light intensity [6]. A combined high temperature and drought tolerance induced by potassium was reported [8]. The role of $\mathrm{K}$ as a nutrient has been recognized for a long time. However, its arrays of biological functions in plant physiological processes have still not been fully explored. In recent years, the correlation between phytohormones and $\mathrm{K}$ has been studied [9]; phytohormones interact with one another and other signaling molecules, which regulate biochemical processes and metabolism, exerting physiological responses in relation to almost all the features of plant growth and development and enhancing stress tolerance. Auxin-regulated genes regulate proteins that affect the transcriptional repressors of stress responses in plants [10]. Abscisic acid (ABA) influences the expression of genes that modulate complex stress-responsive regulatory networks [11]. The roles of other different hormones including cytokinin [12], ethylene and jasmonic acids (JA; [13]), gibberellic acid (GA; [14]), and salicylic acid (SA; [15]) have been documented for their ability to confer abiotic stress tolerance. However, the complex process that occurs in response to abiotic stress tolerance is still under investigation. This is a comprehensive review articulating the biological function of $\mathrm{K}$ in plants and its role in plant adaptations to abiotic stresses.

\section{Biological Functions of Potassium in Plants}

From seed germination to seed production, plants require various macronutrients and micronutrients. Potassium is one of the most important macronutrients, along with nitrogen $(\mathrm{N})$ and phosphorous (P) [16]. Potassium is required for various biochemical and physiological processes that are responsible for plant growth and development. Potassium takes part in protein synthesis, carbohydrate metabolism, and enzyme activation [9]. It assists in the cation-anion balance, osmoregulation, water movement, energy transfer, and many other processes. Potassium also plays a mitigating role in various abiotic stresses such as drought, salinity, metal toxicity, high or chilling temperatures, etc. [9]. When plants experience $\mathrm{K}$ deficiency, they exhibit stunted growth and yellowing in their leaf margins. Moreover, a poor root system, lodging, and yield reductions are common phenomena associated with $\mathrm{K}$ deficiency. A lack of $\mathrm{K}$ fertilizer increases plant susceptibility to various diseases and pest infestation and makes plants vulnerable to damage under various stress conditions [9]. 


\section{Potassium Uptake, Transport, and Assimilation in Plants}

The potassium reserve in soil is very high and accounts for nearly $2.1-2.3 \%$ of the earth's crust $[17,18]$. Therefore, soil $\mathrm{K}$ reserves are generally large [17]. Plants uptake $\mathrm{K}$ as cation $\left(\mathrm{K}^{+}\right)$and many sources of $\mathrm{K}$ are available in soils or provided as fertilizers, including potassium chloride $(\mathrm{KCl})$, potassium nitrate $\left(\mathrm{KNO}_{3}\right)$, potassium sulfate $\left(\mathrm{K}_{2} \mathrm{SO}_{4}\right)$, and potassium carbonate $\left(\mathrm{K}_{2} \mathrm{CO}_{3}\right)$. Among these forms, $\mathrm{KCl}$, or muriate of potash, is the most inexpensive and most frequently used for agronomic crops, with some exceptions [19]. Other forms such as $\mathrm{K}_{2} \mathrm{SO}_{4}$ and $\mathrm{KNO}_{3}$ are used for some crops that are sensitive to chloride $\left(\mathrm{Cl}^{-}\right)$, although they are expensive. For example, $\mathrm{KCl}$ causes leaf burn in tobacco due to its chloride ions [20]. However, the availability of $\mathrm{K}^{+}$from soil or fertilizers depends on the soil texture, soil moisture content, $\mathrm{pH}$, and some other factors. Apart from the common and soluble forms of $\mathrm{K}$ compounds, some forms such as $\mathrm{K}$ silicate minerals are also available in some soils. The availability of these compounds is very low, and in these cases, some microbes (especially bacteria and fungi) assist in solubilizing $\mathrm{K}$ and converting it into soluble forms through acidification, chelation, and exchange reactions [21]. As a macronutrient, $\mathrm{K}$ is mostly applied as a basal dose to the soil. In some cases (e.g., sandy soil), $\mathrm{K}$ is applied as a foliar spray [22]. Foliar application is also very effective under waterlogged conditions [23]. However, the effectiveness of the foliar spray is dependent on the absorption capacity by and penetration into leaves; therefore, it can only partially compensate for insufficient uptake by the roots. Moreover, the efficacy of foliar application also requires a sufficient leaf area [24].

Apart from the factors detailed above, the capacity of plant species to take up $\mathrm{K}^{+}$is another factor that controls $\mathrm{K}$ release from the soil minerals or applied fertilizers. To facilitate $\mathrm{K}^{+}$uptake from the outer environment and transport it to different cellular compartments, many proteins are present in the cell, primarily in the membrane. These proteins are often called transporters and channels. Based on their affinity for $\mathrm{K}^{+}, \mathrm{K}^{+}$transport components can be classified as high-affinity components (transporters), which are active at a low concentration of external $\mathrm{K}^{+}$, and low-affinity components (channels), which are active at a higher concentration, usually at more than $0.3 \mathrm{mM}$ external $\mathrm{K}^{+}$[25]. Advances in molecular approaches and tools have led to the identification of some low-affinity and high-affinity transporters in different plant species including barley (Hordeum vulgare L.), rice (Oryza sativa L.), and capsicum (Capsicum annuum L.) [26]. A yeast mutant lacking the ability to take up $\mathrm{K}^{+}$could grow only when the mutant was transformed with cDNA from barley. This study led to the identification of the high-affinity K transporter HvHAK1, which is homologous to the Escherichia coli and Schwanniomyces occidentalis HAK1 $\mathrm{K}^{+}$transporter [27]. To support the low-affinity transport mechanism as an inward rectifying $\mathrm{K}^{+}$channel, a high-affinity potassium transporters (HKT) has been proposed [26]. An Arabidopsis mutant lacking the HKT1 gene (which was screened from a T-DNA insertion line) was able to grow in a $1 \mathrm{mM} \mathrm{KCl}$ solution without experiencing growth reduction. However, at $100 \mu \mathrm{M} \mathrm{KCl}$, the mutant showed significant growth reduction, indicating HKT1 channel involvement in $\mathrm{K}^{+}$uptake from the low $\mathrm{K}$ solution [28]. In Arabidopsis, 75 genes encode the proteins that facilitate $\mathrm{K}^{+}$uptake and transport. These genes can be roughly categorized into seven categories viz. shaker-type $\mathrm{K}^{+}$channels (nine genes), two-pore $\mathrm{K}^{+}$channels (six genes), putative $\mathrm{K}^{+} / \mathrm{H}^{+}$antiporters (six genes), KUP/HAK/KT transporters (13 genes), HKT transporters (one gene), cyclic-nucleotide gate channels (20 genes), and glutamate receptors [29]. The Shaker-type $\mathrm{K}^{+}$channels were further classified into three groups. These types are an inward-rectifying channel, which facilitates $\mathrm{K}^{+}$uptake and is activated upon hyperpolarization; outward-rectifying channels, which mediate $\mathrm{K}^{+}$efflux and are activated upon membrane depolarization; and weakly rectifying channels, which can function in both $\mathrm{K}^{+}$influx and $\mathrm{K}^{+}$efflux, and they are activated by membrane hyperpolarization [25]. The channels and transporters encoded by different genes are different with respect to structure and function [25].

In roots, the $\mathrm{K}^{+}$uptake from the media is primarily mediated by two proteins, AKT1 and HAK5, because these two proteins are expressed in the roots of Arabidopsis [30] and rice [31,32]. The loss of function mutants hak 5 or akt1 were able to survive at $100 \mu \mathrm{M} \mathrm{KCl}$ solution, but the double hak 5 akt1 mutant failed to survive at the same concentration, indicating that AKT1 and HAK5 are high-affinity 
transporters that mediate sufficient $\mathrm{K}^{+}$uptake for plant growth [30]. In rice, Os-AKT1 mediated $\mathrm{K}^{+}$uptake as regulated by a complex of two proteins, calcineurin B-like protein1 (Os-CBL1) and CBL-interacting protein kinase23 (CIPK23) [31]. For long-distance transport, $\mathrm{K}^{+}$transport from the root cortex to the xylem was mediated by outward-rectifying channels (Figure 1). Experimental evidence showed that a mutant lacking the stellar outward rectifying $\mathrm{K}^{+}$channel (SKOR channel) reduces the $\mathrm{K}^{+}$content in the shoots by $50 \%$ and reduces the $\mathrm{K}^{+}$content in the xylem sap. Stomatal closure or opening depends on the $\mathrm{K}^{+}$concentration in the guard cell, where inward channel KAT1 and KAT2 mediate $\mathrm{K}^{+}$uptake into the cell and outward rectifying $\mathrm{K}^{+}$channel, and the guard cell's outward rectifying $\mathrm{K}^{+}$channel (GORK channel) mediates $\mathrm{K}^{+}$release to close the stomata [33]. In the case of $\mathrm{K}^{+}$, voltage-dependent $\mathrm{K}^{+}$channel (TPK1TPK2, TPK3, and TPK5) and vacuolar $\mathrm{Na}^{+}, \mathrm{K}^{+} / \mathrm{H}^{+}$ antiporters such as NHX1 and NHX2 are present in the tonoplast to facilitate $\mathrm{K}^{+}$influx and efflux in the vacuole [34-36].

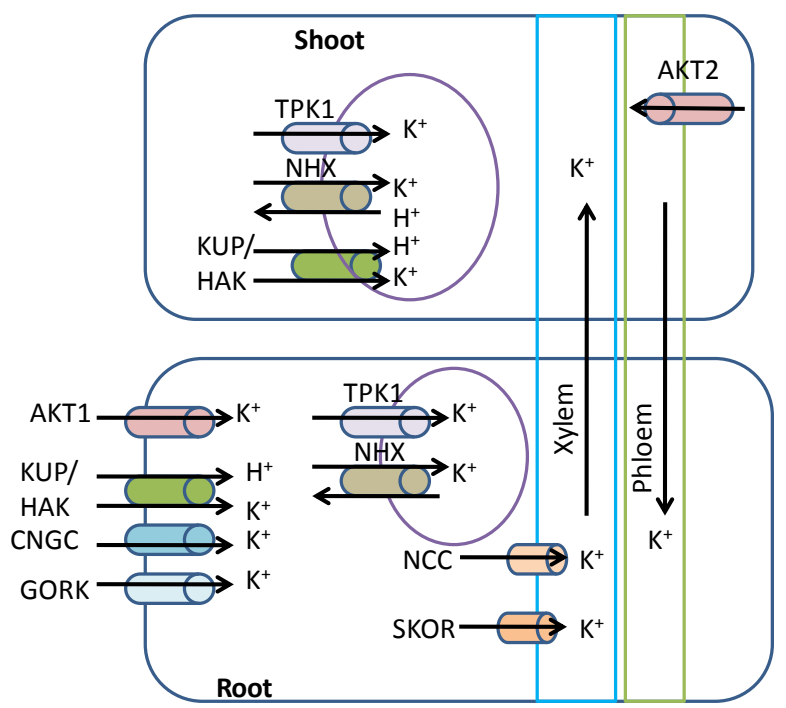

Figure 1. Potassium uptake and transport in plants (Modified from [37]). AKT: Arabidopsis (Shaker-type) $\mathrm{K}^{+}$channel: CNGC: cyclic nucleotide-gated channel; GORK: guard cell outward rectifying $\mathrm{K}^{+}$ channel; HAK/KUP: high affinity $\mathrm{K}^{+}$transporters; KAT: Arabidopsis (Shaker type) $\mathrm{K}^{+}$channel; NCC: non selective cation channels; $\mathrm{NHX}: \mathrm{Na}^{+}$proton exchanger; $\mathrm{SKOR}$ : stelar outward rectifying $\mathrm{K}^{+}$channel; TPK: tonoplast two-pore $\mathrm{K}^{+}$channel.

\section{Potassium and Plant Responses}

Potassium plays significant regulatory roles in numerous plant physiological processes viz. seed germination and emergence, stomatal regulation, phloem transport, cation-anion balance, protein synthesis, photosynthesis, energy transfer, osmoregulation, enzyme activation, nutrient balance, and stress resistance [38].

\subsection{Seed Germination and Emergence}

Potassium assists in seed germination by initiating the rapid imbibition of water, and it also facilitates other physiological processes [39]. Potassium salts have been thoroughly studied as good catalysts for improving seed germination and the emergence rate. The most common forms of $\mathrm{K}$ salts used in seed priming are potassium nitrate $\left(\mathrm{KNO}_{3}\right)$, potassium chloride $(\mathrm{KCl})$ and dipotassium hydrogen phosphate $\left(\mathrm{K}_{2} \mathrm{HPO}_{4}\right)[40,41]$. By using $\mathrm{KNO}_{3}$ as a priming agent, a good germination rate was obtained in cotton genotypes [42]. Osmopriming with $\mathrm{KNO}_{3}$ in rice suggested that $\mathrm{KNO}_{3}$ performed best for the maximum germination percentage and germination rate as well as other morphological attributes [43]. Therefore, in light of the above experimental findings, it can be concluded that $\mathrm{K}$ has a promising regulatory role in seed germination and emergence. 


\subsection{Growth}

Among the essential plant nutrients, $\mathrm{K}$ is an indispensable mineral constituent, intrinsically playing a key role in plant growth and development processes [44]. Maintaining the K level and its ratio with other essential plant nutrients (especially with sodium, $\mathrm{Na}$ ) in plant growth medium or at the cellular level is crucial for normal function as well as the growth of the plant [9]. Moreover, excess or deficient $\mathrm{K}$ in the growing medium hampers the overall growth of the plant. Thus, managing $\mathrm{K}$ fertilizer is advantageous for improving plant growth [45]. Hussain et al. [46] applied different levels of $\mathrm{K}\left(0,30,60,90\right.$, and $120 \mathrm{~kg}$ sulfate of potash (SOP) ha $\left.{ }^{-1}\right)$, and they found a maximum plant height at $90 \mathrm{~kg} \mathrm{SOP} \mathrm{ha}^{-1}$ and a minimum at $0 \mathrm{~kg} \mathrm{ha}^{-1}$. Zelelew et al. [47] experimented on potato (Solanum tuberosum $\mathrm{L}$.) growth with five $\mathrm{K}$ doses $\left(0,75,150,225\right.$, and $300 \mathrm{~kg} \mathrm{~K}_{2} \mathrm{O} \mathrm{ha}^{-1}$ ) and found that the plant height, aerial stem number, and leaf number per plant increased with the increasing $\mathrm{K}$ levels from $0 \mathrm{~kg}$ to $150 \mathrm{~kg} \mathrm{ha}^{-1}$. Gerardeaux et al. [48] observed that the $\mathrm{K}$ deficiency in the vegetative phase of cotton (Gossypium hirsutum L.) reduced the plant dry matter production, leaf area, and internode size, which leads to a reduction in plant growth. Tang et al. [44] cultivated three sweet potato (Ipomoea batatas (L.) Lam.) cultivars in K-deficient soil, and they found a lack of K, notably a cut-off in the total biomass productivity and root yield. Nodulation is a very common phenomenon in legume crops, and it is closely related to plant growth itself. The level of $\mathrm{K}$ and its ratio to $\mathrm{N}$ and $\mathrm{P}$ determine the success of the nodulation process [49].

\subsection{Stomatal Regulation}

Proper stomatal regulation (opening and closing) is necessary for the uninterrupted production of energy during the photosynthesis process, plant cooling, and water and nutrient transport. In the presence of $\mathrm{K}^{+}$, stomatal guard cells are swollen by absorbing water followed by stomatal opening and the allowance of gaseous movement in between plants and the environment. Under water-deficit conditions, $\mathrm{K}^{+}$is pumped out from the guard cell, allowing the pores to close tightly. Thus, $\mathrm{K}$ controls the evapotranspiration (ET) of water through pores under a water deficit in the soil environment, and it protects the plant from water stress [50]. Insufficient $\mathrm{K}$ supply adversely affects stomata functionality, resulting in delayed stomatal closure and even the unfinished closure of the pores. In addition to these effects, the osmotic gradient produced due to the accumulation of $\mathrm{K}$ in the roots helps to draw water into the root cells. Therefore, the reduced K supply in the plant results in decreased water uptake, and the plant faces water stress under drought conditions.

Taiz and Zeiger [51] described the stomatal activity in detail, indicating that the following three major events occur while light radiates into the plant cell and stimulates stomatal opening: the activation of the proton pump ATPase, solute uptake, and organic solute synthesis. The electrochemical potential generated by the proton pump ATPase helps to take up K and its associated anions such as $\mathrm{Cl}^{-}$and malate. While the solute and sucrose amounts increase in the guard cell vacuole, they eventually decrease the osmotic potential. Later, the turgor pressure is increased with the increasing amount of water uptake, resulting in stomatal opening. By contrast, the stomatal closure operation is largely maintained by the ABA content. Calcium uptake is stimulated by ABA, which blocks the $\mathrm{K}^{+}$channel and paves the way to anion $\left(\mathrm{Cl}^{-}\right)$entry into the cell apoplast. An increased concentration of $\mathrm{Ca}^{2+}$ at the intercellular level reduces the proton pump ATPase activity that accelerates cell membrane depolarization, followed by the deportation of cytoplasmic $\mathrm{K}^{+}$to the cell apoplast [52]. Therefore, the stomata close due to reduced turgor pressure.

\subsection{Water Uptake}

Potassium is engaged in nearly all the physiological processes of the plant which require water. These processes include stomatal regulation, the translocation of photoassimilates, enzyme activation, and heliotropic leaf movements. In addition, $\mathrm{K}$ assists in water transportation and mineral compound translocation for the entire plant through the xylem. In cases in which the K supply is not at 
its optimum level, the translocation of mineral compounds such as nitrates $\left(\mathrm{NO}_{3}{ }^{-}\right)$, phosphates $\left(\mathrm{PO}_{4}{ }^{3-}\right)$, calcium $\left(\mathrm{Ca}^{2+}\right)$, magnesium $\left(\mathrm{Mg}^{2+}\right)$, and amino acid uptake is reduced [53]. Optimal $\mathrm{K}$ fertilization helped plants to mitigate the effect of the water deficit through better water use efficiency (WUE), which was related to the lower leaf ET. Martineau et al. [54] reported the appearance of pronounced leaf rolling under a water deficit condition after $\mathrm{K}$ addition, which prevented water losses, and thus, they concluded that adding $\mathrm{K}$ to K-deficient soils can help maize to cope with drought and could be a new management option [54]. The hydraulic conductance of the xylem varies in response to changes in the solute content of the sap, and in particular to the K concentration. This phenomenon, which is known as the ionic effect, is improved in embolized stems, in which it can compensate for the cavitation-induced loss of hydraulic conductance. That report suggests that the potassium concentration in the xylem sap and the hydraulic conductance of well-irrigated laurel plants (Laurus nobilis L.) increased $24 \mathrm{~h}$ after $\mathrm{KCl}$ fertilization [55].

\subsection{Photosynthesis}

Potassium plays an imperative role in the photosynthesis process and the subsequent carbohydrate translocation and metabolism, which eventually increase the crop yield and improve the grain quality [56-58]. Both the leaf number and the leaf size are reduced while the plant is deficient in $\mathrm{K}$. The leaf number and size reduction later hasten the diminished photosynthetic rate per unit leaf area and thus account for an overall reduction in the amount of photosynthetic assimilates available for growth [56]. Furthermore, K controls photosynthesis through sunlight interception. The leaf surface area and sunlight interception were both reduced dramatically when the $\mathrm{K}$ was below the level required by the plant [59].

Stomatal regulation during photosynthesis is a vital event that governs the continual photosynthesis operation, and it is significantly moderated by the amount of $\mathrm{K}$ retained in the plant [38]. Potassium deficiency resulting in reduced stomatal conductance increased the mesophyll resistance and lowered the ribulose-1,5-bisphosphate carboxylase/oxygenase (RuBisCO) activity in plants, which eventually decreased the total photosynthesis rate [60]. The photosynthesis rate in plants increased with the higher utilization and export of photoassimilates. Evidence showed that the sucrose level in the leaves was increased by several folds when the plants were supplied with a sufficient level of $\mathrm{K}$ [60]. In addition, both the photosynthetic $\mathrm{CO}_{2}$ fixation and the utilization of photoassimilates were reduced due to K deficiency, which accelerated the plant ROS production, ultimately hastening rapid photooxidative damage [6]. Thus, the most significant function $\mathrm{K}$ plays in regulating the stomatal aperture is in balancing $\mathrm{CO}_{2}$ entry and $\mathrm{H}_{2} \mathrm{O}$ vapor removal from intercellular spaces. However, the amount of $\mathrm{CO}_{2}$ entry into the intercellular spaces represents the amount of photosynthate production in the leaf. Potassium plays an essential role in activating the ATP synthase enzyme, thus assisting in the photosynthesis process. Shingles and McCarty [61] suggested that the ATPase performance is best when the $\mathrm{K}$ content in the plant is at an optimum level.

However, the molecular identification of the $\mathrm{K}^{+}$transporters involved in photosynthetic regulation has increased the apparent importance of $\mathrm{K}$ in plants. Recent studies have revealed the important roles of three $\mathrm{K}^{+}$efflux antiporters, AtKEA1/2/3 were involved in photosynthesis and primary chloroplast development in Arabidopsis. AtKEA1 and AtKEA2 are located at the inner envelope membrane of the chloroplasts, while AtKEA3 localizes to the thylakoid membrane [62]. Both the chloroplast development and photosynthesis rate were significantly damaged in the AtKEA, 2, 3 triple mutant, resulting in the stunted growth of the mutant plants [62,63]. AtKEA1 and AtKEA2 show polar distribution in small and dividing plastids, which regulate chloroplast development [64]. AtKEA3 is an $\mathrm{H}^{+} / \mathrm{K}^{+}$antiporter that mediates $\mathrm{H}^{+}$efflux from the thylakoid lumen to the stroma through $\mathrm{H}^{+} / \mathrm{K}^{+}$exchange and regulates the proton motive force (pmf) across the thylakoid membranes; and consequently, it regulates photosynthesis as well as photosynthetic acclimation in fluctuating light environments $[65,66]$. 


\subsection{Nutrient Balance}

Under K-deficit condition, protein formation is hampered even when there is an abundant $\mathrm{N}$ supply; therefore, $\mathrm{NO}_{3}{ }^{-}$, amino acids, and amides accumulate in the cell [16]. Potassium activates nitrate reductase (NR), a starch synthetase, and these two enzymes create a balance by producing protein and carbohydrates, respectively. Therefore, $\mathrm{K}$ shortages lead to a breakdown in these processes and the plants suffer, even though other nutrients are available. As previously stated, $\mathrm{K}$ has a role in the xylem and phloem transport system. Consequently, $\mathrm{Ca}^{2+}, \mathrm{Mg}^{2+}, \mathrm{NO}_{3}{ }^{-}$, and $\mathrm{PO}_{4}{ }^{3-}$ as well as plant hormones and enzymes cannot be translocated, and the source-sink relationship is interrupted [67]. The exogenous application of $\mathrm{K}$ at different growth stages decreases the uptake of harmful nutrients, enhancing tolerance to abiotic stress and boosting the yield and yield-related characteristics [68].

Iron $(\mathrm{Fe})$ is another vital micronutrient that also has a synergistic relationship with $\mathrm{K}$ [69]. Under Mo/K deficiency, the Fe uptake is decreased, which leads to the sterility of female flower parts at the reproductive phase, while Mo application increases nodulation in the roots, leading to additional seed yields in lentils [70].

Potassium can also be toxic. During charge compensation, $\mathrm{K}$ is the dominant cation for counterbalancing immobile anions in the cytoplasm, chloroplasts, vacuoles, xylem and phloem. When plants take up excess $\mathrm{K}$, organic acid anions will then accumulate to counterbalance the excess $\mathrm{K}^{+}$transported into the cytoplasm. Notably, with the $\mathrm{K}^{+}$counterbalance anion of $\mathrm{NO}_{3}{ }^{-}$at the time of nitrate metabolism and the reduction of excess $\mathrm{NO}_{3}{ }^{-}$in the leaves, the $\mathrm{K}$ concentration is increased. As a result, organic acids such as malate are synthesized in the leaf tissue to support the charge balance. Part of this K-malate is transported to the root cells for $\mathrm{NO}_{3}{ }^{-}$uptake [38].

\subsection{Reproductive Development}

Potassium plays roles in flowering and pollen germination as well as in seed development. Fan et al. [71] found that externally applied $\mathrm{K}$ helps to increase the pollen germination rate, and $\mathrm{K}$ also increases tube growth in Arabidopsis. Choudhury et al. [72] noted that sucrose, boric acid, and different salts have a role in pollen germination, and among the studied compounds, $\mathrm{KNO}_{3}$ plays an important role in pollen germination and development. Makhdum et al. [73] described that in some cases, the yield depends on the reproductive-vegetative ratio (RVR). If the RVR is lower, then the vegetative growth is higher than the reproductive growth, and in this case, the yield is reduced. Amanullah et al. [45] reported that phenological development such as flowering or physiological maturity was delayed due to the lower application of K. Sadiq and Jan [74] observed that a split application of $\mathrm{K}$ delayed flowering and physiological maturity even after a split application of a $60 \mathrm{~kg} \mathrm{ha}^{-1} \mathrm{~K}$ application, but when using the $90 \mathrm{~kg} \mathrm{ha}^{-1} \mathrm{~K}$ application as a basal dose, the numbers of days to tasseling, silking, and physiological maturity were increased. Asif et al. [75] showed that the phenological development of maize increased with the application of $90 \mathrm{~kg} \mathrm{ha}^{-1} \mathrm{~K}$, and they showed a positive relationship to the number of split $K$ applications. A full dose of $K$ helps to increase the flowering, the number of grains and early physiological maturity. In wheat (Triticum aestivum L.), $\mathrm{K}$ has an important role during the grain filling stage. Applying $\mathrm{K}$ in an appropriate way significantly increased photosynthesis during the grain filling stage, and it also has a positive role in increasing the grain number [76]. The higher amount of $K$ helps to transfer food material to develop grains, thus decreasing the amount of sterile grain. In O. sativa, when the $\mathrm{K}$ was applied at $100 \mathrm{~kg} \mathrm{ha}^{-1}$, the grain sterility was lower compared to the treatment with no $\mathrm{K}$ application. At $100 \mathrm{~kg} \mathrm{~K} \mathrm{ha}^{-1}$, the grain sterility was $22.60 \%$, whereas without $\mathrm{K}$, it was $30.33 \%$ [77].

\subsection{Yield}

Potassium regulates the biosynthesis, conversion, and allocation of metabolites that ultimately increases the yield. Many research works strongly supported the notion that $\mathrm{K}$ is directly or indirectly responsible for higher yield of crops (Table 1). Islam and Muttaleb [77] experimented on rice with 
various doses of $\mathrm{K}$ fertilizer. They reported that $\mathrm{K}$ helps to increase the $\mathrm{N}$ uptake as well as $\mathrm{N}$ use efficiency that help in increasing the yield of rice. As a result, rice yield increased to $6.86 \mathrm{t} \mathrm{ha}^{-1} \mathrm{year}^{-1}$ with optimum doses of $\mathrm{K}$, whereas without $\mathrm{K}$ the yield was $5.19 \mathrm{t} \mathrm{ha}^{-1}$ year $^{-1}$. Cheema et al. [78] found that $\mathrm{K}$ helps to increase the utilization of carbohydrates and it increases the leaf area index, which helps to increase the dry matter accumulation and ultimately increase the yields in rapeseed (Brassica napus L.). Uddin et al. [79] found that 1000 grain weight, grain yield increased by K. Also, when other nutrients are in optimum condition, $\mathrm{K}$ played an important role to increase the yield of NERICA 1 rice. Though other nutrients are available, without $\mathrm{K}$ yield increase is not so much significant. Duan et al. [80] showed that yield of wheat increased by about 0 to $17.6 \%$ when they applied NPK fertilizer compared to only NP, and in case of rice yield increased by about 1.7 to $9.8 \%$ after using NPK fertilizer to only NP. Raza et al. [81] showed that K increased the spike length, number of spikelets per spike, number of grains and grain yield of wheat under drought condition. K increased spike length by $21.8 \%$, number of spikelets spike ${ }^{-1}$ increased by up to $23.27 \%$, number of grains spike $^{-1}$ increased by $39.24 \%$ and ultimately yield was increased by $30.77 \%$ than without $\mathrm{K}$ application . Waraich et al. [82] reported that $200 \mathrm{mM} \mathrm{KNO}_{3}$ application increased the plant branches, plant height, and number of balls plant ${ }^{-1}$ in G. hirsutum but in case of ball weight, $150 \mathrm{mM}$ foliar application is better. According to Colpan et al. [83], K plays a vital role to increase the yield and yield components in tomato (Lycopersicon esculentum L.). They applied various doses of $\mathrm{K}$ as for example 0, 40, 80, 120, and $160 \mathrm{~kg} \mathrm{~K}_{2} \mathrm{O} \mathrm{ha}^{-1}$ and found the highest yield (195.7 $\mathrm{t} \mathrm{ha}^{-1}$ ) with $120 \mathrm{~kg} \mathrm{~K}_{2} \mathrm{O} \mathrm{ha}^{-1}$. Fruit size, diameters of fruits, number of fruits plants ${ }^{-1}$ and fruit weight increased with the application of $\mathrm{K}$. Khan et al. [84] experimented to show the effect of $\mathrm{K}$ on O. sativa and T. aestivum. They noticed that $\mathrm{K}$ increases the yield and yield contributing characters in both crops. In case of $T$. aestivum, yield was about $13 \%$ higher, while in $O$. sativa it was about $50 \%$ higher with the application of $60 \mathrm{~kg} \mathrm{ha}^{-1} \mathrm{~K}$, compared to control.

Table 1. Effect of potassium on different crops to increase yield.

\begin{tabular}{|c|c|c|c|}
\hline Name of Crops & K Doses & Yield Improvement & References \\
\hline Oryza sativa & $60 \mathrm{~kg} \mathrm{~K}_{2} \mathrm{O} \mathrm{ha}^{-1}$ & Grain yield: 50\% & [84] \\
\hline O. sativa & $40 \mathrm{~kg} \mathrm{~K}_{2} \mathrm{O} \mathrm{ha}^{-1}$ & Grain yield: 35\% & [85] \\
\hline O. sativa & $80 \mathrm{~kg} \mathrm{~K}_{2} \mathrm{O} \mathrm{ha}{ }^{-1}$ & Grain yield: $78.47 \%$ & [86] \\
\hline O. sativa & $93.96-112.03 \mathrm{~kg} \mathrm{~K}_{2} \mathrm{O} \mathrm{ha}^{-1}$ & Grain yield: $32.17 \%$ & {$[77]$} \\
\hline Triticum aestivum & $108.42 \mathrm{~kg} \mathrm{~K}_{2} \mathrm{O} \mathrm{ha}^{-1}$ & Grain yield: $10.66 \%$ & [87] \\
\hline O. sativa & $60 \mathrm{~kg} \mathrm{~K}_{2} \mathrm{O} \mathrm{ha} \mathrm{C}^{-1}$ & Grain yield: $13 \%$ & [84] \\
\hline O. sativa & $40 \mathrm{~kg} \mathrm{~K}_{2} \mathrm{O} \mathrm{ha}^{-1}$ & Grain yield: $21 \%$ & [85] \\
\hline O. sativa & $80 \mathrm{~kg} \mathrm{~K}_{2} \mathrm{O} \mathrm{ha}^{-1}$ & Grain yield: $41.16 \%$ & {$[88]$} \\
\hline Lens culinaris & $42.16 \mathrm{~kg} \mathrm{~K}_{2} \mathrm{O} \mathrm{ha}^{-1}$ & Grain yield: $34.16 \%$ & [89] \\
\hline Capsicum annuum & $476.19 \mathrm{~kg} \mathrm{~K}_{2} \mathrm{O} \mathrm{ha}^{-1}$ & Pod/fruit yield: $22.20 \%$ & {$[90]$} \\
\hline Gossypium hirsutum & $112 \mathrm{~kg} \mathrm{~K}_{2} \mathrm{O} \mathrm{ha}^{-1}$ & Lint yield: $10.18 \%$ & [56] \\
\hline G. hirsutum & $150 \mathrm{~kg} \mathrm{~K}_{2} \mathrm{O} \mathrm{ha}^{-1}$ & Lint yield: $13.79 \%$ & [91] \\
\hline G. hirsutum & $180.70 \mathrm{~kg} \mathrm{~K}_{2} \mathrm{O} \mathrm{ha}{ }^{-1}$ & Lint yield: $5.7 \%$ & [92] \\
\hline Solanum tuberosum & $225 \mathrm{~kg} \mathrm{~K}_{2} \mathrm{O} \mathrm{ha}^{-1}$ & Tuber weight: $13.34 \%$ & [93] \\
\hline S. tuberosum & $225 \mathrm{~kg} \mathrm{~K}_{2} \mathrm{O} \mathrm{ha}{ }^{-1}$ & Tuber yield: $78.11 \%$ & [94] \\
\hline S. tuberosum & $150 \mathrm{~kg} \mathrm{~K}_{2} \mathrm{O} \mathrm{ha}^{-1}$ & Tuber yield: $22.41 \%$ & [95] \\
\hline Zea mays & $150 \mathrm{~kg} \mathrm{~K}_{2} \mathrm{O} \mathrm{ha} \mathrm{h}^{-1}$ & Grain yield: $36.33 \%$ & [96] \\
\hline Z. mays & $48.19 \mathrm{~kg} \mathrm{~K}_{2} \mathrm{O} \mathrm{ha}^{-1}$ & Grain yield: $33.12 \%$ & [97] \\
\hline Jatropha curcas & $60 \mathrm{~kg} \mathrm{~K}_{2} \mathrm{O} \mathrm{ha} \mathrm{a}^{-1}$ & Oil yield: $17.30 \%$ & [98] \\
\hline Fragaria $\times$ ananassa & $64 \mathrm{~kg} \mathrm{~K}_{2} \mathrm{O} \mathrm{ha}{ }^{-1}$ & Weight of primary fruits: $6.2 \%$ & [99] \\
\hline Fragaria $\times$ ananassa & $64 \mathrm{~kg} \mathrm{~K}_{2} \mathrm{O} \mathrm{ha}^{-1}$ & Weight of secondary fruits: $6.95 \%$ & [99] \\
\hline Cicer arietinum & $95.23 \mathrm{~kg} \mathrm{~K}_{2} \mathrm{O} \mathrm{ha}^{-1}$ & Grain yield: $34.50 \%$ & [100] \\
\hline Carthamus tinctorius & $95.5 \mathrm{~kg} \mathrm{~K}_{2} \mathrm{O} \mathrm{ha}^{-1}$ & Oil yield: $86.84 \%$ & [101] \\
\hline Arachis hypogaea & $90.35 \mathrm{~kg} \mathrm{~K}_{2} \mathrm{O} \mathrm{ha}{ }^{-1}$ & Seed yield: $44.2 \%$ & [102] \\
\hline Saccharum officinarum & $722.82 \mathrm{~kg} \mathrm{~K}_{2} \mathrm{O} \mathrm{ha}{ }^{-1}$ & Sugar yield: $30.17 \%$ & [103] \\
\hline Betavulgaris & $171.42 \mathrm{~kg} \mathrm{~K}_{2} \mathrm{O} \mathrm{ha}{ }^{-1}$ & Root yield: $24.83 \%$ & [104] \\
\hline Vigna radiata & $37.5 \mathrm{~kg} \mathrm{~K}_{2} \mathrm{O} \mathrm{ha}^{-1}$ & Seed yield: $28.29 \%$ & [105] \\
\hline Lycopersicon esculentum & $120 \mathrm{~kg} \mathrm{~K}_{2} \mathrm{O} \mathrm{ha}{ }^{-1}$ & Seed yield: $30.9 \%$ & [83] \\
\hline
\end{tabular}




\subsection{Crop Quality}

Potassium is responsible not only for higher production but also for the improved quality of the harvest. Thus, $\mathrm{K}$ ensures high-value crops and benefits to growers. $\mathrm{K}$ is sometimes called the "quality element" for its association with better crop production, which is supported by many scientists. Yang et al. [106] showed that the protein percentage in maize (Zea mays L.) grain was higher when a balanced N-P-K fertilizer was applied. However, when only N-P fertilizer was applied, the protein percentage as well as the grain quality was reduced. Nevertheless, when manure was applied along with $\mathrm{N}-\mathrm{P}-\mathrm{K}$ to T. aestivum, the protein percentage was higher than it was under normal fertilization. In T. aestivum, as well as in most of the studied cereal crops, $\mathrm{K}$ helps to provide better milling and baking qualities, a more efficient use of nutrients, increased disease resistance and many other favorable traits. In G. hirsutum, the important quality control parameters are the fiber length, strength, uniformity, micronaire, color, and many others. Many reports strongly support the idea that the fiber quality depends on having optimum levels of $\mathrm{K}$. When the $\mathrm{K}$ supplies are not sufficient, the osmotic potential of the fiber becomes more negative. Thus, the turgor pressure of the fiber decreased and the primary fiber cell wall cannot be elongated, ultimately resulting in shorter fibers [107]. The ginning out turn, fiber uniformity, length, and strength increased when $\mathrm{KNO}_{3}$ was applied at $200 \mathrm{mM}$ as a foliar spray [82]. According to Ashfaq et al. [108], K deficiency reduces the cotton yield and quality. Mehrandish et al. [109] showed that the total soluble solids, soluble sugar content, refineable sugar, and purity percentage of sugarbeet (Beta vulgaris L.) root juice increased with $\mathrm{K}$ application. Economakis and Daskalaki [110] explained that $\mathrm{K}$ increased the dry matter, total soluble solids, firmness, and vitamin $\mathrm{C}$ content in tomatoes under both normal and saline conditions.

\section{Potassium-Induced Abiotic Stress Tolerance}

In the previous sections, we described the role of $\mathrm{K}$ in the various growth and physiological parameters of plants under normal conditions. Many plant studies also showed that $\mathrm{K}$ functions as a vital protector against abiotic stresses. This function is primarily due to its role in maintaining ion homeostasis, cellular integrity and enzymatic activities (Tables 2-4). In the following sections, we will describe the role of $\mathrm{K}$ in conferring tolerance to major abiotic stresses.

\subsection{Drought}

In addition to growth and productivity, $\mathrm{K}$ plays a role in cell turgor maintenance, osmotic adjustment [6], and aquaporin function [9] under drought conditions. A close relationship between the K nutritional status and plant drought resistance has been demonstrated (Table 2).

A sufficient supply of $\mathrm{K}$ can improve the plant dry matter better than a lower concentration of $\mathrm{K}$ can in soil under drought conditions [111]. Increasing root growth, by applying $\mathrm{K}$, increases the root surface area under drought conditions, which ultimately enhances the water uptake by plant cells [112].

The exogenous application of $\mathrm{K}$ not only improved the plant dry matter content and leaf area but also stimulated water uptake when the plants faced drought $[113,114]$. Under drought conditions, excess ROS production in plants may exaggerate cellular lipid peroxidation, leading to an increase in the cellular membrane permeability, which is evidenced by increases in the electrolyte leakage (EL) and malondialdehyde (MDA) content $[115,116]$. Soleimanzadeh et al. [117] performed an experiment with sunflower (Helianthus annuus L.) and reported that an adequate supply of K significantly decreased the MDA content under water shortage conditions which clearly indicates the role of $\mathrm{K}$ in mitigating oxidative stress.

Kanai et al. [118] showed a relationship between the aquaporin activities and the $\mathrm{K}$-channel/transporter, in which $\mathrm{K}$ deficiency markedly changed the $\mathrm{K}^{+}$-channel activity, resulting in an alteration in the root hydraulic conductance and signal transduction with consequent changes in the aquaporin activity. Thus, the reduction in the root hydraulic conductance and water supply 
for transpiration was suppressed under K deficiency. According to Guo et al. [119], there is a positive correlation between water uptake and $\mathrm{K}$ absorption in common bean (Phaseolus vulgaris $\mathrm{L}$.). Potassium mediated the xylem hydraulic conductance and maintained cell turgor, stomatal movement, and sufficient gas exchange as part of the drought adaptation because these events helps to maintain water balance in plants [120].

An adequate supply of $\mathrm{K}$ can reportedly increase the organic osmolyte production under drought conditions, especially Pro [114]. When plants are exposed to drought stress, Pro accumulation plays a highly protective role in plants, and it is involved in osmotic adjustments [121]. In several studies, it was reportedly increased through K application in O. sativa [122], B. napus [123], and T. aestivum under normal and drought stress conditions [124]. Zhang et al. [125] observed that exogenous $\mathrm{K}$ applications increase the Pro content in Z. mays cultivars under drought conditions. At the same time, Ali et al. [126] reported that under drought stress, K applications increase the shoot Pro content in B. napus in a dose-dependent manner. Similarly, Zahoor et al. [127] found that K application generates the Pro content in G. hirsutum during drought stress.

Therefore, proper K supplementation improves the osmotic adjustment and upgrades the plants ability to withstand drought stress. Figure 2 illustrates the involvement of $\mathrm{K}$ in plant tolerance under drought stress.

Table 2. Beneficial effect of exogenous application of potassium under drought stress.

\begin{tabular}{|c|c|c|c|c|}
\hline $\begin{array}{l}\text { Species and } \\
\text { Cultivars }\end{array}$ & $\begin{array}{l}\text { Drought Dose and } \\
\text { Duration }\end{array}$ & K Doses & Protective Effects & References \\
\hline Z. mays & $\begin{array}{l}\text { Withholding water } 31 \text { days } \\
\text { (d) after planting }\end{array}$ & $300 \mathrm{~kg} \mathrm{ha}^{-1}$ & $\begin{array}{l}\text { - } \quad \text { Cell membrane } \\
\text { stability increased } \\
\text { - } \quad \text { Decreased leaf water potential }\end{array}$ & [128] \\
\hline $\begin{array}{l}\text { Hibiscus } \\
\text { rosa-sinensis }\end{array}$ & Water deficit, 21 days & $10 \mathrm{mM}$ & $\begin{array}{l}\text { - } \\
\text { - } \\
\text { Increased root:shoot ratio }\end{array}$ & {$[111]$} \\
\hline Helianthus annuus & $\begin{array}{l}\text { Withholding irrigation at } \\
\text { the end of growing period }\end{array}$ & $100 \mathrm{~kg} \mathrm{ha}^{-1}$ & - $\quad$ Improved shoot dry matter & {$[117]$} \\
\hline Camellia sinensis & Field capacity, 5 days & $2 \% \mathrm{KCl}$ & $\begin{array}{ll}\text { - } & \text { Increased proline (Pro) contents } \\
\text { - } & \text { Improved WUE } \\
\text { - } & \text { Enhanced root starch reserved }\end{array}$ & {$[129]$} \\
\hline T. aestivum & $15 \%$ PEG & $10 \mathrm{mM} \mathrm{K}_{2} \mathrm{O}$ & $\begin{array}{l}\text { - Improved Chlorophyll } a(\operatorname{chl} a) \text {, } \\
\text { chlorophyll } b(\operatorname{chl} b) \text { and } \\
\text { carotenoid (Car) } \\
\text { - Increased Pro content }\end{array}$ & {$[124]$} \\
\hline T. aestivum & $20 \%$ PEG, 7 days & $7.5 \mathrm{mM} \mathrm{K}_{2} \mathrm{CO}_{3}$ & $\begin{array}{ll}\text { - } & \text { Significantly increased shoot } \mathrm{K}^{+} \\
\text {- } & \text { Decreased electrolyte leakage } \\
\text { and MDA }\end{array}$ & {$[130]$} \\
\hline Z. mays & $\begin{array}{l}65 \pm 5 \% \text { water holding } \\
\text { capacity of soil }\end{array}$ & $0.42 \mathrm{~g} \mathrm{~kg}^{-1}$ soil & $\begin{array}{l}\text { - Strengthen the accumulation of } \\
\mathrm{K}^{+} \text {and osmotic nitrides } \\
\text { in plants } \\
\text { - Increased endogenous } \\
\text { glycine betaine }\end{array}$ & {$[125]$} \\
\hline Hordeum vulgare & $50 \%$ soil water content & $10 \mathrm{mM} \mathrm{K}_{2} \mathrm{CO}_{3}$ & $\begin{array}{ll}\text { - } & \text { Enhanced } \mathrm{K}^{+} \text {content in plant } \\
\text { - } & \text { Decreased soluble carbohydrate }\end{array}$ & {$[131]$} \\
\hline O. sativa & $\begin{array}{l}\text { Withholding irrigation } \\
30 \text { days after transplanting, } \\
10 \text { days }\end{array}$ & $120 \mathrm{~kg} \mathrm{ha}^{-1}$ & $\begin{array}{ll} & \text { Increased shoot dry mass } \\
- & \text { Improved osmolytes synthesis }\end{array}$ & {$[114]$} \\
\hline G. hirsutum & $\begin{array}{l}\text { At flowering stage } \\
\text { withholding water for } \\
8 \text { days followed by } \\
75 \pm 5 \% \text { soil relative water } \\
\text { content }\end{array}$ & $300 \mathrm{~kg} \mathrm{ha}^{-1}$ & $\begin{array}{l}\text { - } \quad \text { Improved osmotic adjustment } \\
\text { - } \quad \text { Increased nitrogen metabolism } \\
\text { Enhanced free amino acid, } \\
\text { sugars content }\end{array}$ & {$[127]$} \\
\hline
\end{tabular}




\subsection{Salinity}

Potassium is an important macronutrient that plays essential roles related to the osmotic adjustment, to maintaining turgor and to regulating the membrane potential, cytoplasmic homeostasis, protein synthesis, and enzyme activation under salt stress (Table 3) [132]).

Under salinity stress, the osmotic effect and ion toxicity inhibited plant root growth, which decreases nutrient uptake and translocation, especially that of $\mathrm{K}^{+}$[9]. The sodium ion $\left(\mathrm{Na}^{+}\right)$competes with $\mathrm{K}^{+}$for major binding sites during key metabolic processes in the cytoplasm, with these binding sites including both low-affinity (non-selective cation channels, NSCC) and high-affinity (KUP and high-affinity $\mathrm{K}^{+}$transporter, HKT) transporters; this competition disturbs the plant metabolism $[9,38]$. Salinity induces membrane depolarization and decreases the membrane integrity, which results in $\mathrm{K}^{+}$leakage through depolarization-activated outward-rectifying (KOR) $\mathrm{K}^{+}$ channels [133]. Maintaining the cellular K content above a certain threshold and maintaining a low $\mathrm{Na}^{+} / \mathrm{K}^{+}$ratio is crucial for plant growth and salt tolerance. Thus, higher applications of $\mathrm{K}$ increase the $\mathrm{K}^{+}$content in plant cells and reduce the $\mathrm{Na}^{+}$concentration, which increase the $\mathrm{K}^{+} / \mathrm{Na}^{+}$ratio. The HTK (high-affinity $\mathrm{K}^{+}$transporter) mediates $\mathrm{Na}^{+}$-specific transport or $\mathrm{Na}^{+}-\mathrm{K}^{+}$co-transport, which have vital roles in plant $\mathrm{Na}^{+}$tolerance $[134,135]$.

Table 3. Beneficial effect of exogenous application of potassium under salinity stress.

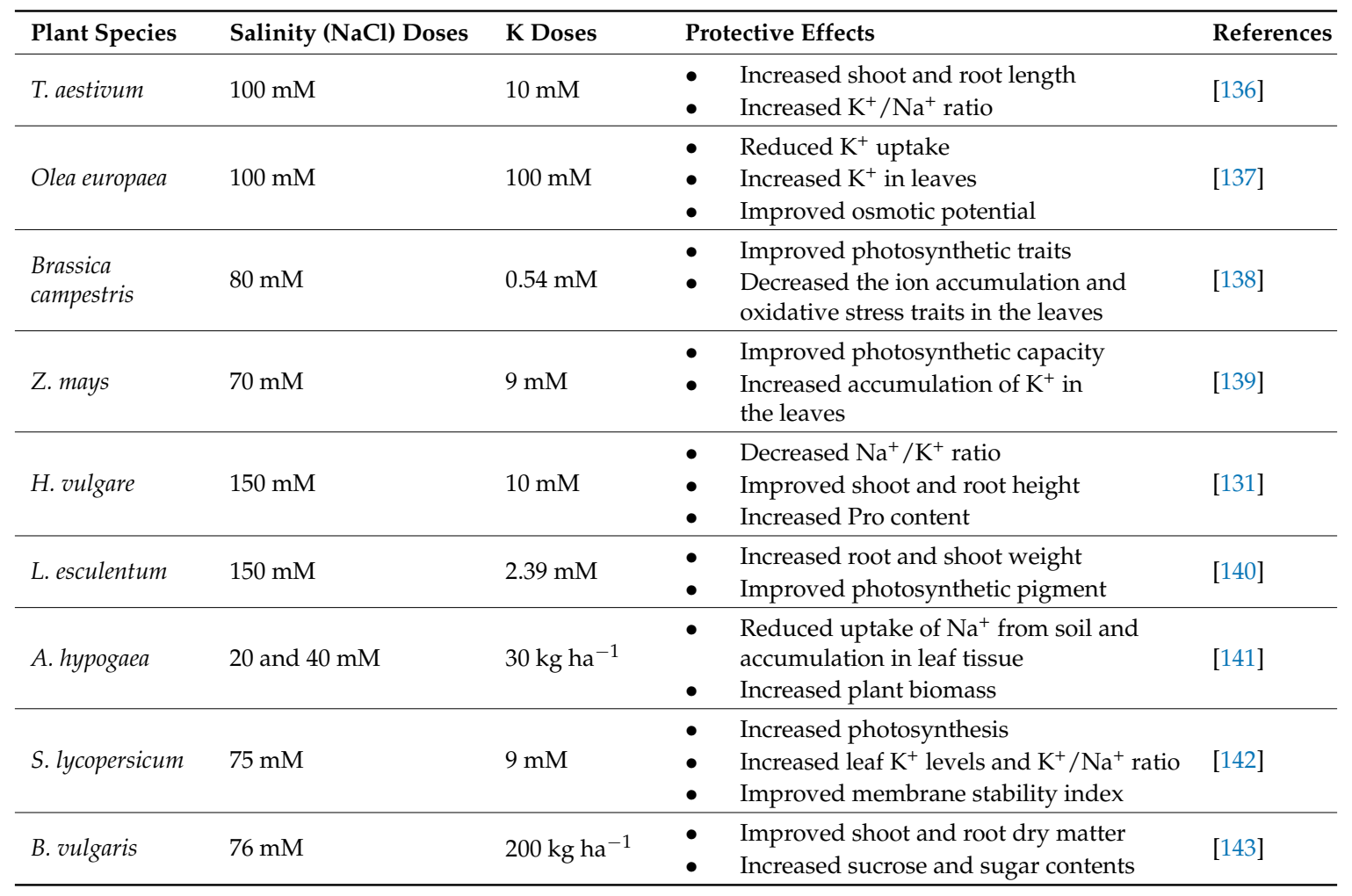




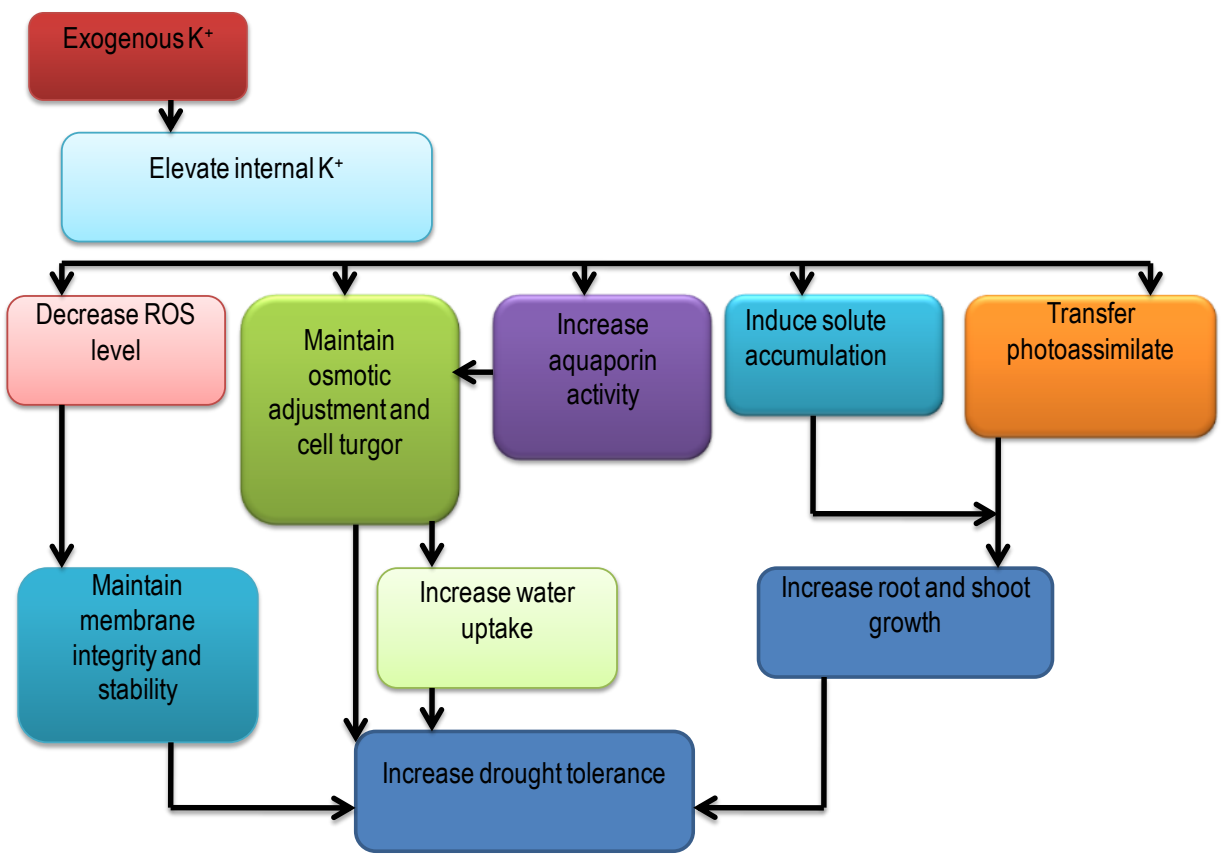

Figure 2. Role of potassium under drought stress (Modified from [9]).

Taffouo et al. [144] found that the $\mathrm{K}^{+}$content was decreased in the roots and shoots due to the reduced uptake and translocation of $\mathrm{K}^{+}$from the roots to the shoots while increasing the $\mathrm{NaCl}$ concentration in Vigna subterranea (L.) Verdc. However, exogenous K can positively correlate with plant root and shoot growth during salinity stress and the K deficient stage. Saida et al. [140] observed that applying $2.39 \mathrm{mM} \mathrm{KH}_{2} \mathrm{PO}_{4}$ against $150 \mathrm{mM} \mathrm{NaCl}$ increased the shoot and root fresh and dry weights of L. esculentum under salt stress. Fayez et al. [131] experimented with a H. vulgare crop and found that under $150 \mathrm{mM} \mathrm{NaCl}$ stress, the shoot fresh weight and height decreased, but treating with $\mathrm{K}$ improved the shoot fresh weight and height of a barley crop. Similarly, Amjad et al. [142] found that applying $9 \mathrm{mM} \mathrm{K}$ improved the root and shoot dry weights under $75 \mathrm{mM} \mathrm{NaCl}$ stress in S. lycopersicum. Merwad [143] reported that higher salinity negatively affected the tomato roots, shoots, leaves and WUE, and they recorded that exogenous $\mathrm{K}$ can have a positive effect on most of the $B$. vulgaris cultivars under salt stress.

In a previous section (Section 5.1), the exogenous application of $\mathrm{K}$ was shown to improve the organic osmolyte synthesis, especially that the rapid rate of cell recovery under osmotic stress was regulated by the higher accumulation of $\mathrm{K}^{+}, \mathrm{Cl}^{-}$, and $\mathrm{Na}^{+}$in the epidermal root cells of Arabidopsis [145]. Thus, higher $\mathrm{Na}^{+}$concentrations are toxic for cell metabolism; that is why it is essential to maintain the cytosolic $\mathrm{K}^{+}$contents at a constant level for plant metabolic processes [146,147]. A constant cytosolic $\mathrm{K}^{+}$concentration is attributed to the consumption of vacuolar $\mathrm{K}^{+}$in $\mathrm{K}^{+}$-deficient situations [9]. Fayez et al. [131] observed that salinity increased the $\mathrm{Na}^{+} / \mathrm{K}^{+}$ratio in $\mathrm{H}$. vulgare, which significantly decreased after the application of $\mathrm{K}$ and increased the $\mathrm{K}^{+} / \mathrm{Na}^{+}$. In addition, Chakraborty et al. [141] suggested that external $\mathrm{K}$ applications could have reduced the $\mathrm{Na}^{+}$uptake by adjusting the tissue ionic balance in peanut (Arachis hypogaea L.).

\subsection{Extreme Temperature}

When the temperature is greater than the optimum, plants suffer from high temperature stress. Extreme temperatures disrupted various biochemical reactions and the plant metabolism, which are highly related to the temperature [3]. Nutrient management is one of the best options for extreme temperature stress tolerance, and among all the nutrients, $\mathrm{K}$ plays a significant role in coping with temperature stress. Potassium helps to activate the various physiological and metabolic processes 
such as photosynthesis, respiration, and nutrient homeostasis, and it increases the tissue water potentiality, which assists in extreme temperature stress tolerance. Under high temperature stress, plants accumulate various types of osmolytes to overcome the damage caused by the stress. Potassium may work as an osmolyte, and it helps to maintain stomatal conductance to prevent damage [148]. In K deficient plants, not only photosynthetic electron transport pathways but also the NADPH oxidizing enzyme reaction produces ROS [5]. In this case, $\mathrm{K}$ helps plants by supporting protein synthesis, stimulating various enzymatic reactions, assisting in carbohydrate production and increasing the WUE. Under heat stress conditions, the foliar spraying of potassium orthophosphate $\left(\mathrm{KH}_{2} \mathrm{PO}_{4}\right)$ helps to increase the heat tolerance of wheat by preventing leaf damage [149]. When a significant amount of $\mathrm{K}$ is lost from the chloroplast, the photosynthesis is reduced. In this situation, $\mathrm{K}$ application helps the plant to tolerate the heat stress by increasing the photosynthetic ability in wheat. Foliar applications of $\mathrm{K}$ also help to increase the translocation and accumulation of photosynthates as well as the dry matter. These factors are related to stress resistance and ultimately help to increase plant yields [150].

When plants face chilling or freezing stress, K-regulated mechanisms such as photosynthesis and carbon assimilation, metabolism, and phloem activity are down-regulated. Seed treatments involving $\mathrm{KCl}$ in a cold-sensitive maize variety led to better ROS defense and ultimately greater tolerance [39]. Plants facing freezing stress were found to lose apoplastic water due to freezing, which causes dehydration; and a sufficient $\mathrm{K}$ supply adjusts the osmotic potential and decreases freezing-induced dehydration [9]. Several field trials in various crops also show a similar phenomenon in which a sufficient $\mathrm{K}$ supply can eliminate frost damage [151].

\subsection{Toxic Metals/Metalloids}

Toxic metal/metalloid contamination in soil is dramatically increasing with time owing to rapid industrialization, which has generated tremendous problems in global agriculture [152]. The most obvious reaction of plants under metal/metalloid toxicity is the inhibited uptake of other essential nutrients and the alteration of almost all the physiological processes, including disturbances in stomatal action, alterations in membrane functions, and the inhibition of photosynthesis, affecting the activities of several key enzymes, the generation of excess ROS, the reduction of the water potential, etc. [153,154]. The continuous reduction in plant growth and development ultimately leads to yield losses as well as food insecurity. Hence, remediating toxic metals in soils or increasing plant tolerance or resistance to stress is a very urgent task for plant scientists. Because $\mathrm{K}$ plays a crucial role in the activation of several enzymes, the synthesis of protein, photosynthetic activity, osmoregulation, the movement of stomata, the transfer of energy, phloem transport, cation-anion balance, and stress resistance [9], this element is used as a plant protector against most abiotic stresses, including metal/metalloid toxicity (Table 4).

Table 4. Exogenous potassium-induced heavy metal stress tolerance in plants.

\begin{tabular}{|c|c|c|c|c|}
\hline Plant Species & Metal Doses & K Doses & Protective Effects of K & References \\
\hline Vicia faba & $200 \mu \mathrm{M} \mathrm{Cd}, 7$ days & $6 \mathrm{mM} \mathrm{K}, 7$ days & $\begin{array}{ll}\text { - } & \text { Increased shoot and root length } \\
\text { - } & \text { Increased chl content } \\
\text { - } & \text { Increased Pro content }\end{array}$ & [155] \\
\hline Prunus persica & $2 \mathrm{mM} \mathrm{ZnCl} 2,10$ days & $\begin{array}{l}10 \mathrm{mM} \mathrm{KCl} \text {, } \\
10 \text { days }\end{array}$ & $\begin{array}{ll} & \text { Improved photosynthesis } \\
\text { - } & \text { Improved plant K } \\
\text { nutritional status }\end{array}$ & [156] \\
\hline $\begin{array}{l}\text { Gladiolus } \\
\text { grandiflora }\end{array}$ & $\begin{array}{l}50 \mathrm{mg} \mathrm{kg}^{-1} \\
\mathrm{CdSO}_{4} \cdot 8 \mathrm{H}_{2} \mathrm{O} \\
60 \text { days }\end{array}$ & 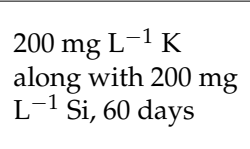 & $\begin{array}{ll}\text { - } & \text { Increased root and shoot length } \\
\text { - } & \text { Increased shoot and root } \\
\text { dry weight } \\
\text { - } & \text { Increased chl content }\end{array}$ & [157] \\
\hline
\end{tabular}

The use of $\mathrm{K}$ against $\mathrm{Cd}$ toxicity confirmed the positive effect of this element by ameliorating Cd-induced oxidative damage in broad bean (Vicia faba L.; [155]). In this study, $6 \mathrm{mM} \mathrm{K}$ was used in combination with $200 \mu \mathrm{M} \mathrm{Cd}$ to inspect the role of the potassium. Cd stress reduced the growth 
parameters (shoot and root lengths), decreased the chl content, altered the enzyme activity and increased the MDA content of the plants. Song et al. [156] experimented with peach plants using elevated exogenous $\mathrm{K}(10 \mathrm{mM})$ against $\mathrm{Zn}$ toxicity $(2 \mathrm{mM})$. They observed that $\mathrm{Zn}$ damages the plant by altering the physiological process and nutritional balance. However, $\mathrm{K}$ mitigated the $\mathrm{Zn}$ toxicity by improving the photosynthesis, antioxidant defense systems, and plant $\mathrm{K}$ nutritional status. Potassium also upregulated the genes related to K acquisition, transport, and homeostasis.

\subsection{High Light}

Several examples illustrated the effect of high light intensity, which caused rapid leaf chlorosis resulted from impaired photosynthesis and photooxidative damages $[158,159]$. With the severity of stress, photosynthetic ability, RuBisCO activity, quantum yield, and electron transport disrupted in tomato [160]. When plants face insufficient $\mathrm{K}$ supply leaf chlorosis increased at high light [6]. This severity decreases the utilization of photoassimilates within the plants under insufficient $K$ supply [161], and transport of sucrose via the phloem decreased [162]. Thus, $\mathrm{K}$ is required in a great quantity to utilize the absorbed high light for $\mathrm{CO}_{2}$ fixation, and source-sink relation. Hence, plants receiving high light intensity may have greater $\mathrm{K}$ demand.

\subsection{Waterlogging}

Among the abiotic stresses waterlogging is an important barrier for crop production and affected at least $10 \%$ of the global agricultural land. When the root zone is waterlogged plants face a severe shortage of oxygen supply (hypoxia or anoxia), which in terms disrupt the respiration process in roots resulted in energy shortage to the cells. The key mechanism is avoiding $\mathrm{K}$ loss, at the time of hypoxia or anoxia, which gives resistance to the plants in waterlogging condition $[163,164]$.

Several researchers have reported the effect of exogenous $\mathrm{K}$ application for ameliorating the adverse effects due to waterlogging. Increased plant height, photosynthetic capacity, and chl content was reported in cotton due to $\mathrm{K}$ supplementation under waterlogging condition [23]. They also found greater nutrient uptake by the plants as a result of higher $\mathrm{K}$ application to soil or foliage [23]. Application of $\mathrm{K}$ at a higher dose improves non-structural carbohydrates (NSC) contents, photosynthetic pigments content and higher antioxidative activity as well as lower lipid peroxidation in submerged rice [165].

\section{Role of Potassium in the Detoxification of Reactive Oxygen Species}

One of the common consequences of abiotic stress is the overproduction of ROS such as singlet oxygen $\left({ }^{1} \mathrm{O}_{2}\right)$, superoxides $\left(\mathrm{O}_{2}{ }^{\bullet-}\right), \mathrm{H}_{2} \mathrm{O}_{2}$ and hydroxyl radicals $\left(\mathrm{OH}^{\bullet}\right)$ [166], alkoxy radicals $\left(\mathrm{RO}^{\bullet}\right)$, peroxy radicals $\left(\mathrm{ROO}^{\bullet}\right)$, and organic hydroperoxides $(\mathrm{ROOH})[167,168]$. Inside plant cells, low concentrations of ROS act as a signaling molecule to protect plants from stresses, while higher concentrations of ROS enhance the lipid peroxidation, oxidation of proteins, inhibition of enzyme activities, and activation of the programmed cell death (PCD) pathway, ultimately leading to cell death [169]. During photosynthetic electron transport and membrane-bound NADPH oxidase reactions, the formation of ROS in plant cells is increased due to K deficiency. Hence, it was suggested that the exogenous use of $\mathrm{K}$ could decrease ROS formation by maintaining the plant photosynthetic electron transport and diminishing the action of NADPH oxidase ([6]; Table 5; Figure 3). 


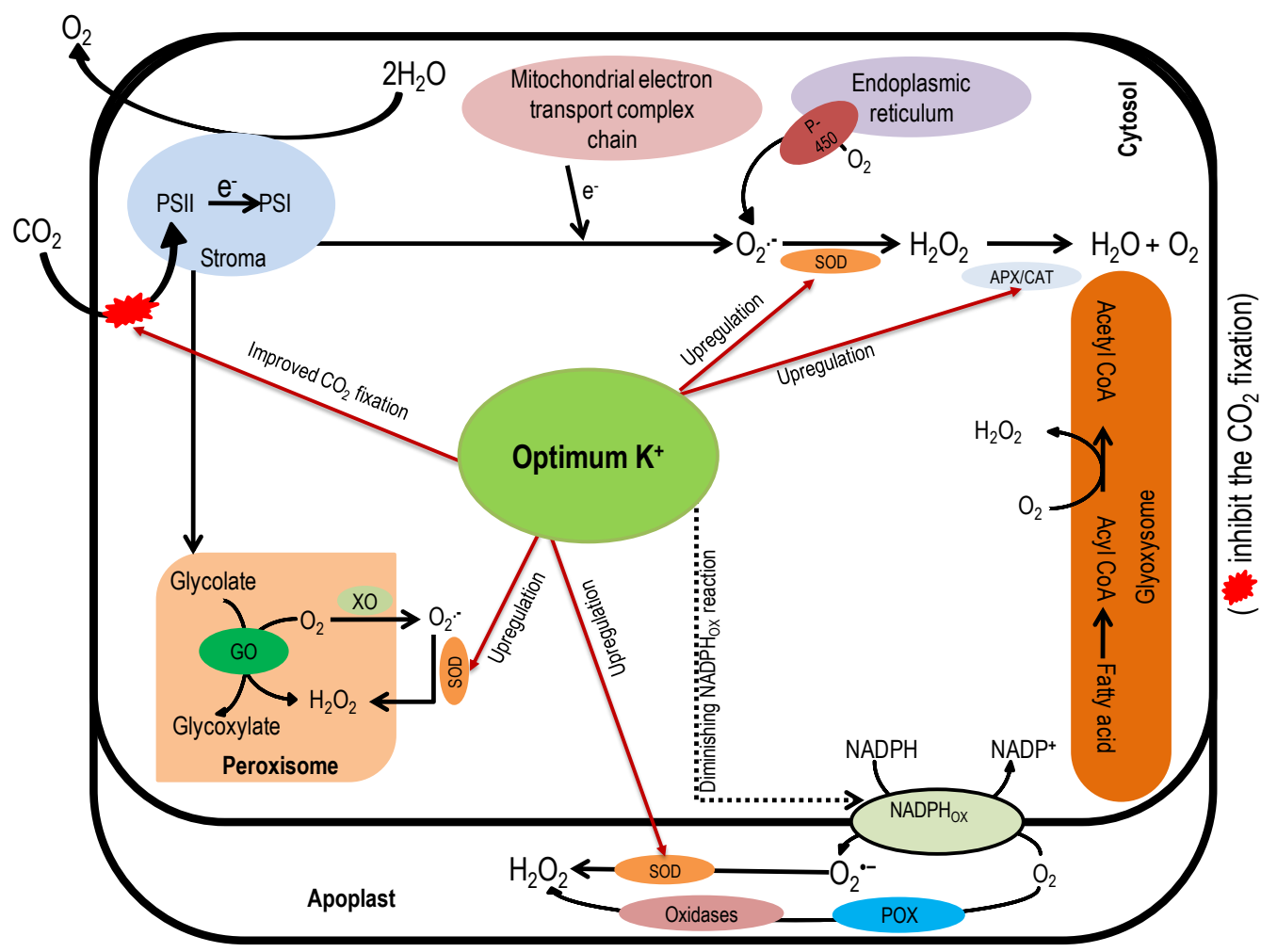

Figure 3. Schematic representation of the role of $\mathrm{K}$ to detoxify the reactive oxygen species (ROS) formation under stress (Modified from [166] with permission from Springer).

Plants that are exposed to environmental stresses such as drought show enhanced K requirements, and furthermore, they show increased oxidative damage to cells by inducing the formation of ROS, especially during photosynthesis [9]. At the time of drought stress, $\mathrm{CO}_{2}$ fixation is limited in plants, and it impacts the stomata regulation, transfer of light into chemical energy and translocation of photosynthates from source to sink (Figure 3; $[170,171]$ ). Due to the impairment of photosynthetic $\mathrm{CO}_{2}$ fixation, plant molecular $\mathrm{O}_{2}$ is activated and ROS production is increased within the plant cell $[6,9,172]$, which causes the degradation of the photosynthetic pigment and cellular membranes. Sangakkara et al. [173] found a positive role for $\mathrm{K}$ by reducing ROS formation and increasing the net photosynthesis rate under water-stressed conditions in mung bean ( $V$. radiata) and the cowpea ( $V$. unguiculata). Egilla et al. [113] observed that adequate $\mathrm{K}^{+}$availability to China rose (Hibiscus rosa-sinensis L.) under drought stress reduced the inhibition of photosynthesis by mitigating ROS formation. Likewise, Milford and Johnston [174] suggested that K plays a vital role in stomatal opening and closing and in the transpiration and photosynthesis of plant cells. Raza et al. [81] experimented with T. aestivum under drought conditions and found that an application of $1.5 \% \mathrm{~K}$ decreased the ROS formation and improved the transpiration and photosynthesis rates. Thus, it was suggested that an adequate supply of $\mathrm{K}$ under drought conditions improved the photosynthetic $\mathrm{CO}_{2}$ fixation and the export of photosynthates from source to sink organs and prevented photosynthetic electron transport to $\mathrm{O}_{2}$. As a result, the formation of ROS was reduced $[6,9]$.

Under saline conditions, low $\mathrm{K}$ increased the toxicity of $\mathrm{Na}^{+}$in plant tissue. Thus, the $\mathrm{K}^{+} / \mathrm{Na}^{+}$ ratio decreased and led to ROS formation, which affects the stomatal closure and inhibits the plant's photosynthesis activity, and it increases oxidative damage [175]. The higher production of ROS due to severe salinity leads to cellular membrane damage. Programmed cell death occurs as a result of $\mathrm{K}^{+}$ leaks from the plant cells due to the activation of $\mathrm{K}^{+}$efflux channels [176]. The external use of $\mathrm{K}$ in a saline growing medium was involved in improving salt tolerance through reduced ROS formation in T. aestivum [177], Z. mays [178], and O. sativa [179]. The application of K enhanced the antioxidant 
enzyme activities such as those of superoxide dismutase (SOD), catalase (CAT), and peroxidase (POD) in zinger (Zingiber officinale Roscoe) [180], which reduced the ROS formation in plant cells. Zheng et al. [181] suggested that applying a suitable amount of $\mathrm{KNO}_{3}$ detoxified the ROS through increased SOD, CAT, and POD enzyme activities in T. aestivum under salt stress. Jan et al. [182] reported that the SOD, CAT, and ascorbate peroxidase (APX) enzyme activities were enhanced, and applying K under salt stress thus detoxified the ROS.

Table 5. Exogenous application of potassium detoxified the ROS formation under stress conditions.

\begin{tabular}{|c|c|c|c|c|}
\hline Plant Species & Levels of Stresses & K Doses & Protective Effects & References \\
\hline Vigna radiata & $\begin{array}{l}\text { Drought }(25 \% \text { and } 50 \% \\
\text { field capacity) }\end{array}$ & $3 \mathrm{mM}$ & $\begin{array}{l}\text { - } \begin{array}{l}\text { Reduced reactive oxygen species } \\
\text { (ROS) production }\end{array} \\
\text { - } \quad \text { Enhanced the rate of net photosynthesis }\end{array}$ & [173] \\
\hline L. esculentus & $60 \mathrm{mM} \mathrm{NaCl}$ & $5 \mathrm{mM}$ & $\begin{array}{ll}\text { - } & \text { Improved chl content } \\
\text { - } & \text { Decreased ROS production } \\
\text { - } & \text { Increased dry matter } \\
\text { - } & \text { Increased water used efficiency }\end{array}$ & [183] \\
\hline H. rosa-sinensis & $\begin{array}{l}\text { Water deficit after } 54 \text { days } \\
\text { of transplanting }\end{array}$ & $10 \mathrm{mM}$ & $\begin{array}{l}\text { - Increased rate of net photosynthesis, } \\
\text { transpiration, and stomatal conductance } \\
\text { Improved leaf water content and leaf } \\
\text { water relations by decreasing the leaf } \\
\text { osmotic potential }(\Psi \pi)\end{array}$ & [113] \\
\hline T. aestivum & $100 \mathrm{mM} \mathrm{NaCl}$ & $16 \mathrm{mM}$ & $\begin{array}{l}\text { Increased superoxide dismutase (SOD), } \\
\text { catalase (CAT) and peroxidase } \\
\text { (POD) activity } \\
\text { - } \quad \text { Reduced the formation of ROS }\end{array}$ & [181] \\
\hline O. sativa & $200 \mathrm{mM} \mathrm{NaCl}$ & $11.8 \mathrm{mM}$ & $\begin{array}{ll}\text { - } & \text { Decreased ROS production } \\
\text { - } & \text { Improved photosynthetic performance }\end{array}$ & [179] \\
\hline T. aestivum & $\begin{array}{l}\text { Water deficit at } \\
\text { milking stage }\end{array}$ & $1.5 \%$ & $\begin{array}{ll}\text { - } & \text { Reduced ROS production } \\
\text { - } & \text { Improved transpiration } \\
\text { and photosynthesis }\end{array}$ & [81] \\
\hline Z. mays & $70 \mathrm{mM} \mathrm{NaCl}$ & $9 \mathrm{mM}$ & $\begin{array}{ll}\text { - } & \text { Increased CAT activity } \\
\text { - } & \text { Improved photosynthetic capacity } \\
\text { - } & \text { Increased accumulation of } \mathrm{K} \text { in the leaves }\end{array}$ & [139] \\
\hline $\begin{array}{l}\text { Solanum } \\
\text { lycopersicum }\end{array}$ & $150 \mathrm{mM} \mathrm{NaCl}$ & $9 \mathrm{mM}$ & 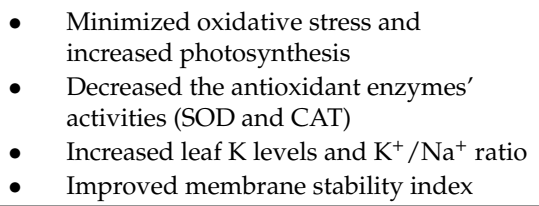 & [142] \\
\hline T. aestivum & $8.56 \mathrm{mM} \mathrm{NaCl}$ & $0.49 \mathrm{mM}$ & $\begin{array}{ll}\text { - } & \text { Increased SOD, CAT, ascorbate } \\
& \text { peroxidase (APX) activity } \\
\text { - } & \text { Improved photosynthetic capacity } \\
\text { - } & \text { Reduced ROS formation }\end{array}$ & [182] \\
\hline
\end{tabular}

On the other hand, NADPH-oxidizing enzymes reduce $\mathrm{O}_{2}$ to $\mathrm{O}_{2}{ }^{-}$by using NADPH as an electron donor ([6]; Figure 3). Moreover, the NADPH oxidase activity was substantially enhanced under $\mathrm{K}$ deficiency, increasing the NADPH-dependent $\mathrm{O}_{2}{ }^{-}$production. Cakmak [6] found that $\mathrm{K}$ deficiency increased the NADPH oxidase activity in the cytosol of P. vulgaris roots, with a corresponding increase in the NADPH-dependent $\mathrm{O}_{2}{ }^{-}$generation, but exogenous $\mathrm{K}$ decreased the NADPH oxidase activity. Potassium deficiency is most likely the primary reason for the increased NADPH oxidase and NADPH-dependent ROS formation through the generation of ABA. Peuke et al. [184] experimented with castor (Ricinus communis) and found that $\mathrm{K}$ deficiency increased the biosynthesis of ABA in roots and increased the translocation of ABA from the roots to the shoots. Moreover, ABA has likewise appeared to be effective at increasing the accumulation of $\mathrm{H}_{2} \mathrm{O}_{2}$ and $\mathrm{O}_{2}{ }^{-}$in plant roots $[185,186]$, but this point needs to be verified in future studies. It is clear that an improvement in the $\mathrm{K}$ status maintains the photosynthetic electron transport and inhibits the NADPH oxidase activities, which reduce ROS formation in plants. 


\section{Interaction of Potassium with Other Biomolecules}

Potassium is called the policeman nutrient; it plays an important role in the growth, development, and yield as well as the metabolism of plants. It also has some interactive regulatory functions with other biomolecules $[5,9]$. Therefore, $\mathrm{K}$ deficiency leads to dysfunction in numerous physiological and biochemical processes; for example, in the water balance, enzyme activity, and charge balance, in addition to tolerance to biotic and abiotic stresses [187]. Potassium is also essential for the function and performance of many plant enzymes; at least 60 enzymes require $K$ as a cofactor for activation [188]. These enzymes regulate the vital metabolic mechanisms in arable plants $[38,189]$. To increase substrate attraction, $\mathrm{K}$ binds with the specific binding site of inactive enzymes, resulting in their activation, and these enzymes were involved in various metabolic and physiological mechanisms. Several studies have suggested that the activity of nitrate reductase (NR), RuBisCO, starch synthase, sucrose phosphate synthase, $\beta$-amylase, invertase, phosphofructokinase, and pyruvate kinase greatly depends on the $\mathrm{K}$ sufficiency of plants $[190,191]$.

Among the biomolecules, carbohydrates have a greater interactive relation with $\mathrm{K}$. When plants obtain enough $\mathrm{K}$, they synthesize large biomolecules; for example, cellulose, starch, protein, etc. As a result, the number of small molecules such as free sugars, amino acids, organic acids, and amides are reduced in the cell while the concentration of phenols increases, and these compounds aid in plant resistance [192] and increase the plant response to abiotic stress [193]. Carbohydrates, mostly in terms of hexose content, are decreased in leaves due to a sufficient $\mathrm{K}$ supply, which was transported to another plant organ due to better phloem activity. On the other hand, K deficiency resulted in the decreased activity of pyruvate kinase and / or increased invertase activity that reduces the concentration of starch in leaves because of the inhibition of starch synthase [60].

Potassium has a positive relationship to plant hormone synthesis as well [194]. When the K concentration in the cell is low, JA and auxin biosynthesis are upregulated [195], but ethylene synthesis is increased by two-fold in Arabidopsis when the plant is suffering from K-starvation [196], and the other biological functions decreased in the roots and xylem sap, leading to sucrose accumulation. Conversely, the cytokinin concentrations in the leaf and the xylem sap decreased when plants obtained sufficient amounts of $\mathrm{K}[187,197]$. Ethylene, which is another important plant hormone, assists in the progression of root morphology and stimulates ROS biosynthesis to tolerate a low $\mathrm{K}$ condition in Arabidopsis [198]. Exogenously applied K and naphthaleneacetic acid (NAA) can interact significantly to increase the growth and yield of $V$. radiata [199]. A similar result was also obtained by applying K and GA to rice [200] and by applying K and SA to olive trees under salinity [201]. Increased levels of JA, hydroxy-12-oxo-octadecadienoic acids (HODs), and 12-oxo-phytodienoic acid (OPDA) were obtained under K-starved conditions along with the upregulation of the 13-lipoxygenase (LOX) pathway, indicating the transcript levels of several biosynthetic enzymes with $K$ interactions [202]. ABA acts as an important signal-mediated factor during the transduction of the sucrose regulation signal. The ABA content in the seed is negatively correlated with the sucrose content, and the ABA/(Indole acetic acid + $\mathrm{GA}+$ cytokinin) ratio is influenced by $\mathrm{K}$ nutrition in a way that particularly reduces the ABA content, playing a key role in the increase in the sucrose content, which suggested the $\mathrm{K}$ interactions with phytohormones [187].

Polyamines also have a role in a wide range of environmental stresses, and they are involved in various physiological processes. Their concentrations at the cellular level increased under $\mathrm{K}$ deficit conditions in oat (Avena sativa L.) [203]. When plants face any stress, they accumulate polyamines at a higher concentration. Polyamines have significant interactions with $\mathrm{K}$ at the cellular level, and they regulate the plasma membrane $\mathrm{K}^{+}$channel of the guard cells, modulating stomatal regulation [204]. The authors also reported that spermidine, spermine, cadaverine, and putrescine powerfully block the opening and closing of stomata, which provides a link among the stress, the stomatal regulation, and the polyamine level. 


\section{Potassium-Induced Abiotic Stress Signaling}

In a dynamic environment, the K content of the soil may not remain the same over the growing period of a crop. Interestingly, plant roots can sense fluctuations in the $\mathrm{K}^{+}$availability. When the $\mathrm{K}$ deficiency is sensed by plant roots, a series of events occurs in the plant at the molecular level to cope with this condition. Some signaling components are involved from the signal perception to the adaptive responses (Figure 4). For example, the $\mathrm{Ca}^{2+}$ signaling, ROS, microRNA, membrane potential and phytohormones are the signaling components [25,52]. Under K-deficient conditions, CIPK23 (a protein kinase) activates the $\mathrm{K}^{+}$transporter AKT1 by phosphorylation. The calcium sensors CBL1 and CBL2 regulate the activation of CIPK23 [205]. Later, low $\mathrm{K}^{+}$induces two distinct $\mathrm{Ca}^{2+}$ signals that are read by CBL1/9, as observed in A. thaliana [206]. The CBL1/9 then regulates the AKT1 by activating CBL1/9-CIPK23 complexes [206]. The overexpression of the type III peroxidase RCI3 increased the production of ROS as well as the HAK5 expression. However, a mutant lacking this gene exhibited reductions in both ROS production and HAK5 expression, indicating the relationship between the ROS and the low K response [207]. Potassium channels such as NSCC and GORK are very sensitive to ROS. Under saline conditions, the ROS-mediated activation of NSCC and GORK is the primary reason for the $\mathrm{K}$ pool reduction in the cytosol $[29,208]$. A prolonged $\mathrm{K}$ deficiency in the cytosol activates different endonucleases and proteases, which in turn causes cell death [29].

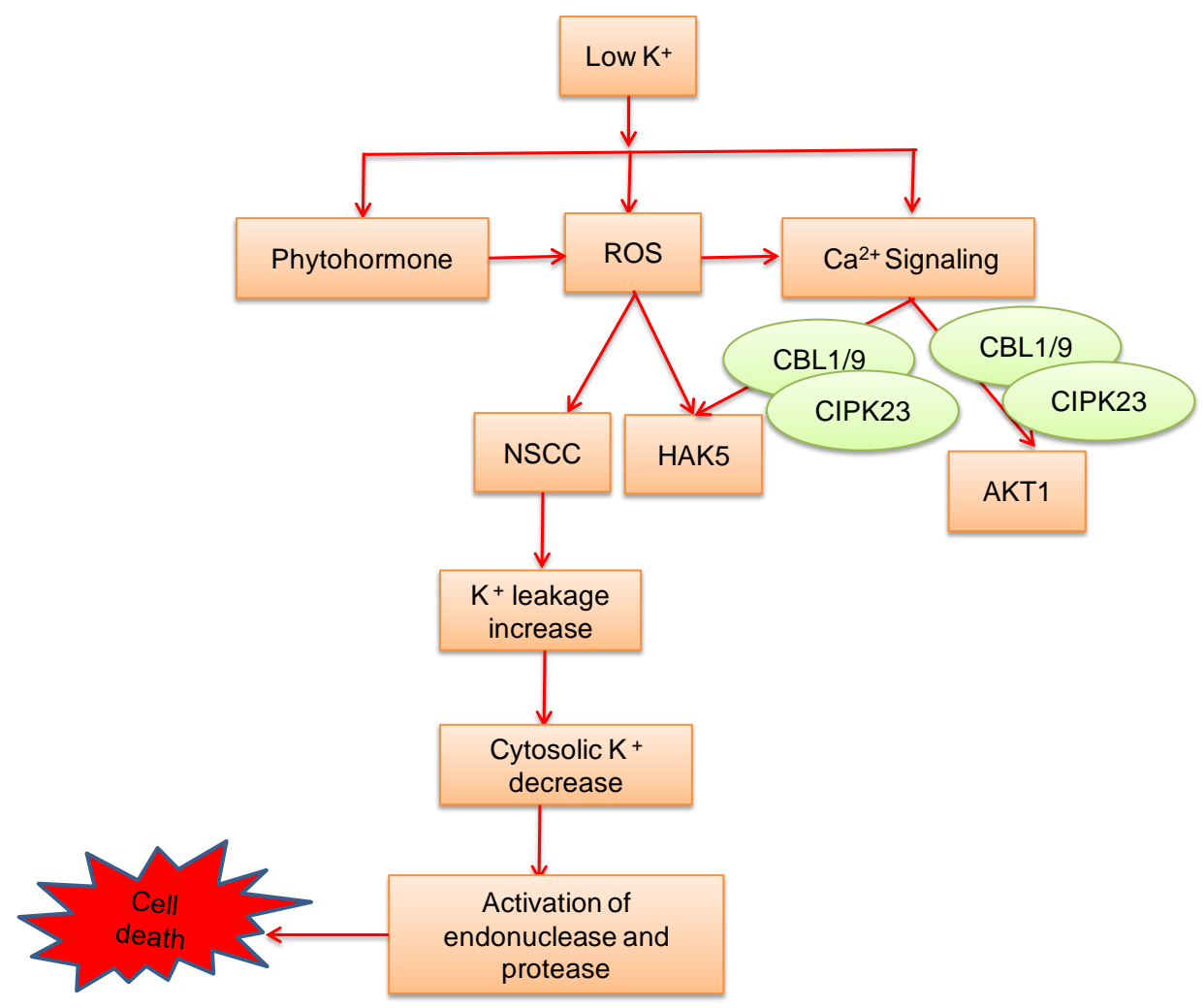

Figure 4. K-induced signaling in the plant. ROS: Reactive oxygen species; NSCC: Non-selective cation channel; HAK5 and AKT1: $\mathrm{K}^{+}$transporter, CBL1/9: calcineurin B-like proteins, CIPK23: A protein kinase.

Phytohormones such as ethylene, auxin, cytokinin, and JA are also involved in low K-induced signaling processes. Under K-deficient conditions, HAK5 transcription is regulated by the upstream signaling molecule ethylene and ROS [209]. However, the cytokinin content decreases under low K stress to regulate HAK5 by inducing ROS [209]. $\mathrm{A} \mathrm{K}^{+}$transporter in rice has been found to be regulated by JA [210]. The involvement of microRNAs in plant nutrient homeostasis has been reported in many 
studies. For example, the gene chip overexpression of OsmiR399 increased the nutrient contents of the plant, including the contents of $\mathrm{K}^{+}$. Under nutrient starvation, OsmiR399 expression increases [211]. The elucidation of a complex pathway that was induced by $\mathrm{K}$ signaling allowed us to engineer the pathway in a way that would ensure the optimum $\mathrm{K}$ level in the plant.

\section{Conclusions}

Potassium is vital for plant survival under both physiological and stress conditions. It is not only a part of the chemical structure but also plays vital regulatory functions in biochemical and physiological processes that contribute to plant growth and development. Proper use of $\mathrm{K}$ with other nutrients helps to attain sustainable productivity and quality of crops and ensure nutritional food security for animals and human beings. As a sessile organism, plant is continuously disturbed by a range of abiotic and biotic stresses. Among the abiotic stresses, drought, salinity, toxic metal, high temperature, chilling, high light intensity, waterlogging, etc., they exert their deleterious effects in crop plants. Important physiological activities including photosynthesis are greatly hampered under most of the abiotic stresses, which lead to increased toxic ROS in the plant cell. But adequate K supply to the plants during stress condition can lessen the production of ROS and improve the plant condition. Potassium also works in plant signaling systems which helps to defend some stresses by activating antioxidant defense systems. Thus, this review assesses $\mathrm{K}$ involvement in normal plant growth and development, in addition to increasing tolerance/resistance against different stress conditions.

Acknowledgments: We thank Sayed Mohammad Mohsin and Khursheda Parvin, Faculty of Agriculture, Sher-e-Bangla Agricultural University for their critical reading and formatting of the manuscript.

Author Contributions: M.H. and M.F. planned and made the outline of this review and wrote some parts. M.H. edited the manuscript. All other authors contributed equally in writing the contents.

Conflicts of Interest: The authors declare no conflict of interest.

\section{References}

1. Wani, S.H.; Sah, S.K. Biotechnology and abiotic stress tolerance in rice. J. Rice Res. 2014, 2, $1000-1105$. [CrossRef]

2. Hasanuzzaman, M.; Nahar, K.; Fujita, M. Plant response to salt stress and role of exogenous protectants to mitigate salt-induced damages. In Ecophysiology and Responses of Plants under Salt Stress; Ahmad, P., Azooz, M.M., Prasad, M.N.V., Eds.; Springer: New York, NY, USA, 2013; pp. 25-87.

3. Hasanuzzaman, M.; Nahar, K.; Alam, M.M.; Roychowdhury, R.; Fujita, M. Physiological, biochemical, and molecular mechanisms of heat stress tolerance in plants. Int. J. Mol. Sci. 2013, 14, 9643-9684. [CrossRef] [PubMed]

4. Jedmowski, C.; Ashoub, A.; Momtaz, O.; Brüggemann, W. Impact of drought, heat, and their combination on chlorophyll fluorescence and yield of wild barley (Hordeum spontaneum). J. Bot. 2015. [CrossRef]

5. Cakmak, I. The role of potassium in alleviating detrimental effects of abiotic stresses in plants. J. Plant Nutr. Soil Sci. 2005, 168, 521-530. [CrossRef]

6. Waraich, E.A.; Ahmad, R.; Halim, A.; Aziz, T. Alleviation of temperature stress by nutrient management in crop plants: A review. J. Soil Sci. Plant Nutr. 2012, 12, 221-244. [CrossRef]

7. O'Neill, S.D.; Spanswick, R.M. Characterization of native and reconstituted plasma membrane $\mathrm{H}^{+}$-ATPase from the plasma membrane of Beta vulgaris. J. Membr. Biol. 1984, 79, 245-256. [CrossRef]

8. Halford, N.G. New insights on the effects of heat stress on crops. J. Exp. Bot. 2009, 60, 4215-4216. [CrossRef] [PubMed]

9. Wang, M.; Zheng, Q.; Shen, Q.; Guo, S. The critical role of potassium in plant stress response. Int. J. Mol. Sci. 2013, 14, 7370-7390. [CrossRef] [PubMed]

10. Shani, E.; Salehin, M.; Zhang, Y.; Sanchez, S.E.; Doherty, C.; Wang, R.; Mangado, C.C.; Song, L.; Tal, I.; Pisanty, O.; et al. Plant stress tolerance requires auxin-sensitive Aux/IAA transcriptional repressors. Curr. Biol. 2017, 27, 437-444. [CrossRef] [PubMed] 
11. Song, L.; Huang, S.C.; Wise, A.; Castanon, R.; Nery, J.R.; Chen, H.; Watanabe, M.; Thomas, J.; Bar-Joseph, Z.; Ecker, J.R. A transcription factor hierarchy defines an environmental stress response network. Science 2016, 354. [CrossRef] [PubMed]

12. Zwack, P.J.; Rashotte, A.M. Interactions between cytokinin signalling and abiotic stress responses. J. Exp. Bot. 2015, 66, 4863-4871. [CrossRef] [PubMed]

13. Kazan, K. Diverse roles of jasmonates and ethylene in abiotic stress tolerance. Trends Plant Sci. 2015, 20, 219-229. [CrossRef] [PubMed]

14. Colebrook, E.H.; Thomas, S.G.; Phillips, A.L.; Hedden, P. The role of gibberellin signalling in plant responses to abiotic stress. J. Exp. Biol. 2014, 217, 67-75. [CrossRef] [PubMed]

15. Anjum, N.A.; Khan, N.A. Salicylic acid-induced abiotic stress tolerance and underlying mechanisms in plants. Front. Plant Sci. 2015, 6, 462. [CrossRef]

16. Fageria, N.K. The Use of Nutrients in Crop Plants; CRC Press: Boca Raton, FL, USA, 2016.

17. Schroeder, D. Structure and weathering of potassium containing minerals. In Proceedings of the 11th Congress of the International Potash Institute, Tokyo, Japan, 27-28 August 1978; International Potash Institute: Bern, Switzerland, 1978.

18. Wedepohl, K.H. The composition of the continental crust. Geochim. Cosmochim. Acta 1995, 59, 1217-1232. [CrossRef]

19. Kafkafi, U.; Xu, G.; Imas, P.; Magen, H.; Tarchitzky, J. Potassium and Chloride in Crops and Soils: The Role of Potassium Chloride Fertilizer in Crop Nutrition; IPI Research Topics No. 22; International Potash Institute: Horgen, Switzerlands, 2001; p. 220.

20. Ishizaki, H.; Akiya, T. Effects of chlorine on growth and quality of tobacco. Jpn. Agric. Res. Q. 1978, 12, 1-6.

21. Masood, S.; Bano, A. Mechanism of potassium solubilization in the agricultural soils by the help of soil microorganisms. In Potassium Solubilizing Microorganisms for Sustainable Agriculture; Meena, V., Maurya, B., Verma, J., Meena, R., Eds.; Springer: New Delhi, India, 2016; pp. 137-147.

22. Sarkar, R.K.; Malik, G.C. Effect of foliar spray of potassium nitrate and calcium nitrate on grasspea (Lathyrus sativus L.) grown in rice fallows. Lathyrus Lathyrism Newsl. 2001, 2, 47-48.

23. Ashraf, M.A.; Ahmad, M.S.A.; Ashraf, M.; Al-Qurainy, F.; Ashraf, M.Y. Alleviation of waterlogging stress in upland cotton (Gossypium hirsutum L.) by exogenous application of potassium in soil and as a foliar spray. Crop Past. Sci. 2011, 6, 25-38. [CrossRef]

24. Ling, F.; Silberbush, M. Response of maize to foliar vs. soil application of nitrogen-phosphorus-potassium fertilizers. J. Plant Nutr. 2002, 25, 2333-2342. [CrossRef]

25. Wang, Y.; Wu, W.H. Potassium transport and signaling in higher plants. Annu. Rev. Plant Biol. 2013, 64, 451-476. [CrossRef] [PubMed]

26. Nieves-Cordones, M.; Alemán, F.; Martínez, V.; Rubio, F. $\mathrm{K}^{+}$uptake in plant roots. The systems involved, their regulation and parallels in other organisms. J. Plant Physiol. 2014, 171, 688-695. [CrossRef] [PubMed]

27. Santa-María, G.E.; Rubio, F.; Dubcovsky, J.; Rodríguez-Navarro, A. The HAK1 gene of barley is a member of a large gene family and encodes a high-affinity potassium transporter. Plant Cell 1997, 9, 2281-2289. [CrossRef] [PubMed]

28. Hirsch, R.E.; Lewis, B.D.; Spalding, E.P.; Sussman, M.R. A role for the AKT1 potassium channel in plant nutrition. Science 1998, 280, 918-921. [CrossRef] [PubMed]

29. Anschütz, U.; Becker, D.; Shabala, S. Going beyond nutrition: Regulation of potassium homoeostasis as a common denominator of plant adaptive responses to environment. J. Plant Physiol. 2014, 171, 670-687. [CrossRef] [PubMed]

30. Pyo, Y.J.; Gierth, M.; Schroeder, J.I.; Cho, M.H. High-affinity $\mathrm{K}^{+}$transport in Arabidopsis: AtHAK5 and AKT1 are vital for seedling establishment and postgermination growth under low-potassium conditions. Plant Physiol. 2010, 153, 863-875. [CrossRef] [PubMed]

31. Li, J.; Long, Y.; Qi, G.N.; Xu, Z.J.; Wu, W.H.; Wang, Y. The Os-AKT1 channel is critical for $\mathrm{K}^{+}$uptake in rice roots and is modulated by the rice CBL1-CIPK23 complex. Plant Cell 2014, 26, 3387-3402. [CrossRef] [PubMed]

32. Yang, T.; Zhang, S.; Hu, Y.; Wu, F.; Hu, Q.; Chen, G.; Cai, J.; Wu, T.; Moran, N.; Yu, L.; et al. The role of a potassium transporter OsHAK5 in potassium acquisition and transport from roots to shoots in rice at low potassium supply levels. Plant Physiol. 2014, 166, 945-959. [CrossRef] [PubMed] 
33. Hosy, E.; Vavasseur, A.; Mouline, K.; Dreyer, I.; Gaymard, F. The Arabidopsis outward $\mathrm{K}^{+}$channel GORK is involved in regulation of stomatal movements and plant transpiration. Proc. Natl. Acad. Sci. USA 2003, 100, 5549-5554. [CrossRef] [PubMed]

34. Gobert, A.; Isayenkov, S.; Voelker, C.; Czempinski, K.; Maathuis, F.J.M. The two-pore channel TPK1 gene encodes the vacuolar $\mathrm{K}^{+}$conductance and plays a role in $\mathrm{K}^{+}$homeostasis. Proc. Natl. Acad. Sci. USA 2007, 104, 10726-10731. [CrossRef] [PubMed]

35. Bassil, E.; Tajima, H.; Liang, Y.C.; Ohto, M.A.; Ushijima, K. The Arabidopsis $\mathrm{Na}^{+} / \mathrm{H}^{+}$antiporters NHX1 and $\mathrm{NHX} 2$ control vacuolar $\mathrm{pH}$ and $\mathrm{K}^{+}$homeostasis to regulate growth, flower development, and reproduction. Plant Cell 2011, 23, 3482-3497. [CrossRef] [PubMed]

36. Barragan, V.; Leidi, E.O.; Andrés, Z.; Rubio, L.; De Luca, A.; Fernandez, A.; Cubero, B.; Pardo, J.M. Ion exchangers NHX1 and NHX2 mediate active potassium uptake into vacuoles to regulate cell turgor and stomatal function in Arabidopsis. Plant Cell 2012, 24, 1127-1142. [CrossRef] [PubMed]

37. Ahmad, I.; Maathuis, F.J. Cellular and tissue distribution of potassium: Physiological relevance, mechanisms and regulation. J. Plant Physiol. 2014, 171, 708-714. [CrossRef] [PubMed]

38. Marschner, H. Marschner's Mineral Nutrition of Higher Plants, 3rd ed.; Academic Press: London, UK, 2012; pp. 178-189.

39. Farooq, M.; Basra, S.M.A.; Rehman, H.; Saleem, B.A. Seed priming enhances the performance of late sown wheat (Triticum aestivum L.) by improving chilling tolerance. J. Agron. Crop Sci. 2008, 194, 55-60. [CrossRef]

40. Copeland, L.O.; McDonald, M.B. Seed Science and Technology; Chapman \& Hill: New York, NY, USA, 2001.

41. Mohammadi, G.R. The effect of seed priming on plant traits of late-spring seeded soybean (Glycine max L.). Am. Eur. J. Agric. Environ. Sci. 2009, 5, 322-326.

42. Çokkizgin, H.; Bölek, Y. Priming treatments for improvement of germination and emergence of cotton seeds at low temperature. Plant Breed. Seed Sci. 2015, 71, 121-134. [CrossRef]

43. Esmeili, M.A.; Heidarzade, A. Investigation of different osmopriming techniques on seed and seedling properties of rice (Oryza sativa) genotypes. Int. Res. J. Basic Appl. Sci. 2012, 3, 242-246.

44. Tang, Z.H.; Zhang, A.J.; Wei, M.; Chen, X.G.; Liu, Z.H.; Li, H.M.; Ding, Y.F. Physiological response to potassium deficiency in three sweet potato (Ipomoea batatas [L.] Lam.) genotypes differing in potassium utilization efficiency. Acta Physiol. Plant. 2015, 37, 184. [CrossRef]

45. Iqbal, A.; Hidayat, Z. Potassium management for improving growth and grain yield of maize (Zea mays L.) under moisture stress condition. Sci. Rep. 2016, 6, 34627. [CrossRef]

46. Hussain, F.; Malik, A.U.; Haji, M.A.; Malghani, A.L. Growth and yield response of two cultivars of mungbean (Vigna radiata L.) to different potassium levels. J. Anim. Plant Sci. 2011, 21, 622-625.

47. Zelelew, D.Z.; Lal, S.; Kidane, T.T.; Ghebreslassie, B.M. Effect of potassium levels on growth and productivity of potato varieties. Am. J. Plant Sci. 2016, 7, 1629-1638. [CrossRef]

48. Gerardeaux, E.; Jordan-Meille, L.; Constantin, J.; Pellerin, S.; Dingkuhn, M. Changes in plant morphology and dry matter partitioning caused by potassium deficiency in Gossypium hirsutum L. Environ. Exp. Bot. 2010, 67, 451-459. [CrossRef]

49. Divito, G.A.; Sadras, V.O. How do phosphorus, potassium and sulphur affect plant growth and biological nitrogen fixation in crop and pasture legumes? A meta-analysis. Field Crops Res. 2014, 156, 161-171. [CrossRef]

50. Thomas, T.C.; Thomas, A.C. Vital role of potassium in the osmotic mechanism of stomata aperture modulation and its link with potassium deficiency. Plant Signal. Behav. 2009, 4, 240-243.

51. Taiz, L.; Zeiger, E. Plant Physiology, 5th ed.; Sinauer: Sunderland, MA, USA, 2010.

52. Wang, Y.; Wu, W.H. Regulation of potassium transport and signaling in plants. Curr. Opin. Plant Biol. 2017, 39, 123-128. [CrossRef] [PubMed]

53. Schwartzkopf, C.A.R.L. Potassium, Calcium, Magnesium-How They Relate to Plant Growth. Available online: http://gsrpdf.lib.msu.edu/ticpdf.py?file=/1970s/1972/721101.pdf (accessed on 11 March 2018).

54. Martineau, E.; Domec, J.C.; Bosc, A.; Denoroy, P.; Fandino, V.A.; Lavres, J., Jr.; Jordan-Meille, L. The effects of potassium nutrition on water use in field-grown maize (Zea mays L.). Environ. Exp. Bot. 2017, 134, 62-71. [CrossRef]

55. Oddo, E.; Inzerillo, S.; Grisafi, F.; Sajeva, M.; Salleo, S.; Nardini, A. Does short-term potassium fertilization improve recovery from drought stress in laurel? Tree Physiol. 2014, 34, 906-913. [CrossRef] [PubMed] 
56. Pettigrew, W.T. Potassium influences on yield and quality production for maize, wheat, soybean and cotton. Physiol. Plant. 2008, 133, 670-681. [CrossRef] [PubMed]

57. Zorb, C.; Senbayram, M.; Peiter, E. Potassium in agriculture-Status and perspectives. J. Plant Physiol. 2014, 171, 656-669. [CrossRef] [PubMed]

58. Lu, Z.; Lu, J.; Pan, Y.; Lu, P.; Li, X.; Cong, R.; Ren, T. Anatomical variation of mesophyll conductance under potassium deficiency has a vital role in determining leaf photosynthesis. Plant Cell Environ. 2016, 39, 2428-2439. [CrossRef] [PubMed]

59. Bednarz, C.W.; Oosterhuis, D.M.; Evans, R.D. Leaf photosynthesis and carbon isotope discrimination of cotton in response to potassium deficiency. Environ. Exp. Bot. 1998, 39, 131-139. [CrossRef]

60. Zhao, D.; Oosterhuis, D.M.; Bednarz, C.W. Influence of potassium deficiency on photosynthesis, chlorophyll content, and chloroplast ultrastructure of cotton plants. Photosynthetica 2001, 39, 103-109. [CrossRef]

61. Shingles, R.; McCarty, R.E. Direct measurement of ATP-dependent proton concentration changes and characterization of a K-stimulated ATPase in pea chloroplast inner envelope vesicles. Plant Physiol. 1994, 106, 731-737. [CrossRef] [PubMed]

62. Kunz, H.H.; Gierth, M.; Herdean, A.; Satoh-Cruz, M.; Kramer, D.M.; Spetea, C.; Schroeder, J.I. Plastidial transporters KEA1, -2 , and -3 are essential for chloroplast osmoregulation, integrity, and $\mathrm{pH}$ regulation in Arabidopsis. Proc. Natl. Acad. Sci. USA 2014, 111, 7480-7485. [CrossRef] [PubMed]

63. Dana, S.; Herdean, A.; Lundin, B.; Spetea, C. Each of the chloroplast potassium efflux antiporters affects photosynthesis and growth of fully developed Arabidopsis rosettes under short day photoperiod. Physiol. Plant. 2016, 158, 483-491. [CrossRef] [PubMed]

64. Aranda-Sicilia, M.N.; Aboukila, A.; Armbruster, U.; Cagnac, O.; Schumann, T.; Kunz, H.H.; Jahns, P.; Rodrı'guez-Rosales, M.P.; Sze, H.; Venema, K. Envelope $\mathrm{K}^{+} / \mathrm{H}^{+}$antiporters AtKEA1 and AtKEA2 function in plastid development. Plant Physiol. 2016, 172, 441-449. [CrossRef] [PubMed]

65. Armbruster, U.; Carrillo, L.R.; Venema, K.; Pavlovic, L.; Schmidtmann, E.; Kornfeld, A.; Jahns, P.; Berry, J.A.; Kramer, D.M.; Jonikas, M.C. Ion antiport accelerates photosynthetic acclimation in fluctuating light environments. Nat. Commun. 2014, 5, 5439. [CrossRef] [PubMed]

66. Wang, C.; Yamamoto, H.; Narumiya, F.; Munekage, Y.N.; Finazzi, G.; Szabo, I.; Shikanai, T. Fine-tuned regulation of the $\mathrm{K}^{+} / \mathrm{H}^{+}$antiporter KEA3 is required to optimize photosynthesis during induction. Plant J. 2017, 89, 540-553. [CrossRef] [PubMed]

67. Coskun, D.; Britto, D.T.; Kronzucker, H.J. The nitrogen-potassium intersection: Membranes, metabolism, and mechanism. Plant Cell Environ. 2017, 40, 2029-2041. [CrossRef] [PubMed]

68. Ganie, A.H.; Ahmad, A.; Yousuf, P.Y.; Pandey, R.; Ahmad, S.; Aref, I.M.; Iqbal, M. Nitrogen-regulated changes in total amino acid profile of maize genotypes having contrasting response to nitrogen deficit. Protoplasma 2017, 254, 2143-2153. [CrossRef] [PubMed]

69. Tewari, R.K.; Hadacek, F.; Sassmann, S.; Lang, I. Iron deprivation-induced reactive oxygen species generation leads to non-autolytic PCD in Brassica napus leaves. Environ. Exp. Bot. 2013, 91, 74-83. [CrossRef] [PubMed]

70. Omer, F.A.; Abbas, D.N.; Khalaf, A.S. Effect of molybdenum and potassium application on nodulation, growth and yield of lentil (Lens culinaris Medic). Pak. J. Bot. 2016, 48, 2255-2259.

71. Fan, L.; Wang, Y.; Wang, H.; Wu, W. In vitro Arabidopsis pollen germination an characterization of inward potassium currents in Arabidopsis pollen grain protoplasts. J. Exp. Bot. 2001, 52, 1603-1614. [CrossRef] [PubMed]

72. Choudhury, S.; Mondal, S.; Mandal, S. Studies on in vitro pollen germination of Carissa carandus L. Sci. Cult. 2013, 79, 128-130.

73. Makhdum, M.I.; Pervez, H.; Ashraf, M. Dry matter accumulation and partitioning in cotton (Gossypium hirsutum L.) as influenced by potassium fertilization. Biol. Fertil. Soils 2007, 43, $295-301$. [CrossRef]

74. Sadiq, S.A.; Jan, A. Effect of Graded Application of Potash on Kharif Maize Sown at Different Fertility Levels. M.Sc (Hons) Thesis, Department of Agron, KPK Agricultural University, Peshawar, Pakistan, 2001.

75. Asif, M.; Anwar, M. Phenology, leaf area and yield of spring maize (Cv. Azam) as affected by levels and timings of potassium application. World Appl. Sci. J. 2007, 2, 299-303.

76. Zou, T.X.; Dai, T.B.; Jiang, D.; Jing, Q.; Cao, W.X. Effects of nitrogen and potassium application levels on flag leaf photosynthetic characteristics after anthesis in winter wheat. Acta Agron. Sin. 2007, 33, 1667-1673. 
77. Islam, A.; Muttaleb, A. Effect of potassium fertilization on yield and potassium nutrition of Boro rice in a wetland ecosystem of Bangladesh. Arch. Agron. Soil Sci. 2016, 62, 1530-1540. [CrossRef]

78. Cheema, M.A.; Wahid, M.A.; Sattar, A.; Rasul, F.; Saleem, M.F. Influence of different levels of potassium on growth, yield and quality of canola (Brassica napus L.) cultivars. Pak. J. Agric. Sci. 2012, 49, 163-168.

79. Uddin, S.; Sarkar, M.A.R.; Rahman, M.M. Effect of nitrogen and potassium on yield of dry direct seeded rice cv. Nerica 1 in Aus season. Int. J. Agron. Plant Prod. 2013, 4, 69-75.

80. Duan, Y.; Shi, X.; Li, S.; Sun, X.; He, X. Nitrogen use efficiency as affected by phosphorus and potassium in long-term rice and wheat. J. Integr. Agric. 2014, 13, 588-596. [CrossRef]

81. Raza, M.A.S.; Saleem, M.F.; Shah, G.M.; Khan, I.H.; Raza, A. Exogenous application of glycinebetaine and potassium for improving water relations and grain yield of wheat under drought. J. Soil Sci. Plant Nutr. 2014, 14, 348-364. [CrossRef]

82. Waraich, E.A.; Ahmad, R.; Hur, R.G.M.; Ahmad, A.; Mahmood, N. Response of foliar application of $\mathrm{KNO}_{3}$ on yield, yield components and lint quality of cotton (Gossypium hirsutum L.). Afr. J. Agric. Res. 2011, 6, 5457-5463.

83. Colpan, E.; Zengin, M.; Özbahçe, A. The effects of potassium on the yield and fruit quality components of stick tomato. Hortic. Environ. Biotechnol. 2013, 54, 20-28. [CrossRef]

84. Khan, R.; Gurmani, A.R.; Gurmani, A.H.; Zia, M.S. Effect of potassium application on crop yields under wheat-rice system. Sarhad J. Agric. 2007, 23, 277-279.

85. Hussain, F.; Yasin, M. Soil Fertility Monitoring and Management in Rice-Wheat System; Annual Report LRRP; National Agricultural Research Centre (NARC): Islamabad, Pakistan, 2003; pp. 1-16.

86. Islam, A.; Chandrabiswas, J.; Karim, A.J.M.S.; Salmapervin, M.; Saleque, M.A. Effects of potassium fertilization on growth and yield of wetland rice in grey terrace soils of Bangladesh. Res. Crop Ecophysiol. 2015, 10, 64-82.

87. Tahir, M.; Tanveer, A.; Ali, A.; Ashraf, M.; Wasaya, A. Growth and yield response of two wheat (Triticum aestivum L.) varieties to different potassium levels. Pak. J. Life Soc. Sci. 2008, 6, 92-95.

88. Maurya, P.; Kumar, V.; Maurya, K.K.; Kumawat, N.; Kumar, R. Effect of potassium application on growth and yield of wheat varieties. Bioscan 2014, 9, 1371-1373.

89. Jahan, S.A.; Alim, M.A.; Hasan, M.M.; Kabiraj, U.K.; Hossain, M.B. Effect of potassium levels on the growth, yield and yield attributes of lentil. Int. J. Sustain. Crop Prod. 2009, 4, 1-6.

90. El-Bassiony, A.M.; Fawzy, Z.F.; El-Samad, E.A.; Riad, G.S. Growth, yield and fruit quality of sweet pepper plants (Capsicum annuum L.) as affected by potassium fertilization. Am. J. Sci. 2010, 6, 722-729.

91. Gormus, O.; Yucel, C. Different planting date and potassium fertility effects on cotton yield and fiber properties in the Cukurova region, Turkey. Field Crop Res. 2002, 78, 141-149. [CrossRef]

92. Dong, H.; Kong, X.; Li, W.; Tang, W.; Zhang, D. Effects of plant density and nitrogen and potassium fertilization on cotton yield and uptake of major nutrients in two fields with varying fertility. Field Crops Res. 2010, 119, 106-113. [CrossRef]

93. Bansal, S.K.; Trehan, S.P. Effect of potassium on yield and processing quality attributes of potato. Karnataka J. Agric. Sci. 2011, 24, 48-54.

94. Al-Moshileh, A.M.; Errebi, M.A. Effect of various potassium sulfate rates on growth, yield and quality of potato grown under sandy soil and arid conditions. In Proceedings of the InIPI Regional Workshop on Potassium and Fertigation Development in West Asia and North Africa, Rabat, Morocco, 24-28 November 2004; pp. 24-28.

95. Pervez, M.A.; Ayyub, C.M.; Shaheen, M.R.; Noor, M.A. Determination of physiomorphological characteristics of potato crop regulated by potassium management. Pak. J. Agric. Sci. 2013, 50, 611-615.

96. Tariq, M.U.; Saeed, A.; Nisar, M.U.; Mian, I.A.; Afzal, M. Effect of potassium rates and sources on the growth performance and on chloride accumulation of maize in two different textured soils of Haripur, Hazara division. Sarhad J. Agric. 2011, 27, 415-422.

97. Farhad, I.S.; Islam, M.N.; Hoque, S.; Bhuiyan, M.S. Role of potassium and sulphur on the growth, yield and oil content of soybean (Glycine max L.). Acad. J. Plant Sci. 2010, 3, 99-103.

98. Tikkoo, A.; Yadav, S.S.; Kaushik, N. Effect of irrigation, nitrogen and potassium on seed yield and oil content of Jatropha curcas in coarse textured soils of northwest India. Soil Tillage Res. 2013, 134, 142-146. [CrossRef] 
99. Eshghi, S.; Safizadeh, M.R.; Jamali, B.; Sarseifi, M. Influence of foliar application of volk oil, dormex, gibberellic acid and potassium nitrate on vegetative growth and reproductive characteristics of strawberry cv. 'Merak'. J. Biol. Environ. Sci. 2012, 6, 35-38.

100. Goud, V.V.; Konde, N.M.; Mohod, P.V.; Kharche, V.K. Response of chickpea to potassium fertilization on yield, quality, soil fertility and economic in vertisols. Legum. Res. 2012, 37, 311-315. [CrossRef]

101. Abbadi, J.; Gerendás, J.; Sattelmacher, B. Effects of potassium supply on growth and yield of safflower as compared to sunflower. J. Plant Nutr. Soil Sci. 2008, 171, 272-280. [CrossRef]

102. Umar, S. Alleviating adverse effects of water stress on yield of sorghum, mustard, and groundnut by potassium application. Pak. J. Bot. 2006, 38, 1373-1380.

103. Ng Kee Kwong, K.F. The effects of potassium on growth, development, yield and quality of sugarcane. In Potassium for Sustainable Crop Production, Proceedings of the International Symposium on the Role of Potassium in Nutrient Management for Sustainable Crop Production in India, New Delhi, India, 3-5 December 2001; Pasricha, N.S., Bansal, S.K., Eds.; Potash Research Institute of India (PRII) and International Potash Institute (IPI): Horgen, Switzerland, 2002; pp. 430-444.

104. Abdel-Mawly, S.E.; Zanouny, I. Response of sugar beet (Beta vulgaris L.) to potassium application and irrigation with saline water. Assiut Univ. Bull Environ. Res. 2004, 7, 123-136.

105. Abbas, G.; Aslam, M.; Malik, A.U.; Abbas, Z.; Ali, M.; Hussain, F. Potassium sulfate effects on growth and yield of mungbean (Vigna radiata L.) under arid climate. Int. J. Agric. Appl. Sci. 2011, 3, 72-75.

106. Yang, S.; Fengmin, L.; Malhi, S.S.; Wang, P.; Suo, D.; Wang, J. Long-term fertilization efforts on crop yield and nitrate nitrogen accumulation in soil in northwestern China. Agron. J. 2004, 96, 1039-1049. [CrossRef]

107. Pettigrew, W.T. Relationship between insufficient potassium and crop maturity in cotton. Agron. J. 2003, 95, 1323-1329. [CrossRef]

108. Ashfaq, A.; Hussain, N.; Athar, M. Role of potassium fertilizers in plant growth, crop yield and quality fiber production of cotton-An overview. FUUAST J. Biol. 2015, 5, 27-35.

109. Mehrandish, M.; Moeini, M.J.; Armin, M. Sugar beet (Beta vulgaris L.) response to potassium application under full and deficit irrigation. Eur. J. Exp. Biol. 2012, 2, 2113-2119.

110. Economakis, C.; Daskalaki, A. Effect of potassium nutrition on yield and quality of tomato plants grown with nutrient film technique under sodium chloride saline conditions. Acta Hortic. 2003, 609, 337-339. [CrossRef]

111. Egilla, J.N.; Davies, F.T.; Drew, M.C. Effect of potassium on drought resistance of Hibiscus rosa-sinensis cv. Leprechaun: Plant growth, leaf macro- and micronutrient content and root longevity. Plant Soil 2001, 229, 213-224. [CrossRef]

112. Römheld, V.; Kirkby, E.A. Research on potassium in agriculture: Needs and prospects. Plant Soil 2010, 335, 155-180. [CrossRef]

113. Egilla, J.N.; Davies, F.T.; Boutton, T.W. Drought stress influences leaf water content, photosynthesis, and water-use efficiency of Hibiscus rosa-sinensis at three potassium concentrations. Photosynthetica 2005, 43, 135-140. [CrossRef]

114. Zain, N.A.M.; Ismail, M.R.; Puteh, A.; Mahmood, M.; Islam, M.R. Drought tolerance and ion accumulation of rice following application of additional potassium fertilizer. Commun. Soil Sci. Plant Anal. 2014, 45, 2502-2514. [CrossRef]

115. Fazeli, F.; Ghorbanli, M.; Niknam, V. Effect of drought on biomass, protein content, lipid peroxidation and antioxidant enzymes in two sesame cultivars. Biol. Plant. 2007, 51, 98-103. [CrossRef]

116. Degenkolbe, T.; Do, P.T.; Zuther, E.; Repsilber, D.; Walther, D.; Hincha, D.K.; Köhl, K.I. Expression profiling of rice cultivars differing in their tolerance to long-term drought stress. Plant Mol. Biol. 2009, 69, 133-153. [CrossRef] [PubMed]

117. Soleimanzadeh, H.; Habibi, D.; Ardakani, M.R.; Paknejad, F.; Rejali, F. Effect of potassium levels on antioxidant enzymes and malondialdehyde content under drought stress in sunflower (Helianthus annuus L.). Am. J. Agric. Biol. Sci. 2010, 5, 56-61. [CrossRef]

118. Kanai, S.; Moghaieb, R.E.; El-Shemy, H.A.; Panigrahi, R.; Mohapatra, P.K.; Ito, J.; Nguyen, N.T.; Saneoka, H.; Fujita, K. Potassium deficiency affects water status and photosynthetic rate of the vegetative sink in green house tomato prior to its effects on source activity. Plant Sci. 2011, 180, 368-374. [CrossRef] [PubMed]

119. Guo, S.W.; Shen, Q.R.; Brueck, H. Effects of local nitrogen supply on water uptake of bean plants in a split root system. J. Integr. Plant Biol. 2007, 49, 472-480. [CrossRef] 
120. Oddo, E.; Inzerillo, S.; La Bella, F.; Grisafi, F.; Salleo, S.; Nardini, A. Short-term effects of potassium fertilization on the hydraulic conductance of Laurus nobilis L. Tree Physiol. 2011, 31, 131-138. [CrossRef] [PubMed]

121. Teixeira, J.; Pereira, S. High salinity and drought act on an organ-dependant manner on potato glutamine synthetase expression and accumulation. Environ. Exp. Bot. 2007, 60, 121-126. [CrossRef]

122. Pandey, R.; Agarwal, R.M.; Jeevaratnam, K.; Sharma, G.L. Osmotic stress induced alterations in rice (Oryza sativa L.) and recovery. Plant Growth Regul. 2004, 42, 79-87. [CrossRef]

123. Din, J.; Khan, S.U.; Ali, I.; Gurmani, A.R. Physiological and agronomic response of canola varieties to drought stress. J. Anim. Plant Sci. 2011, 21, 78-83.

124. Jatav, K.S.; Agarwal, R.M.; Singh, R.P.; Shrivastava, M. Growth and yield responses of wheat (Triticum aestivum L.) to suboptimal water supply and different potassium doses. J. Funct. Environ. Bot. 2012, 2, 39-51. [CrossRef]

125. Zhang, L.; Gao, M.; Li, S.; Alva, A.K.; Ashraf, M. Potassium fertilization mitigates the adverse effects of drought on selected Zea mays cultivars. Turk. J. Bot. 2014, 38, 713-723. [CrossRef]

126. Ali, M.; Bakhat, J.; Khan, G.D. Effect of water deficiency and potassium application on plant growth, osmolytes and grain yield of Brassica napus L. cultivars. Acta Bot. Croat. 2014, 73, 299-314. [CrossRef]

127. Zahoor, R.; Zhao, W.; Abid, M.; Dong, H.; Zhou, Z. Potassium application regulates nitrogen metabolism and osmotic adjustment in cotton (Gossypium hirsutum L.) functional leaf under drought stress. J. Plant Physiol. 2017, 215, 30-38. [CrossRef] [PubMed]

128. Premachandra, G.S.; Saneoka, H.; Ogata, S. Cell membrane stability and leaf water relationsas affected potassium nutrition of water-stressed maize. J. Exp. Bot. 1991, 42, 739-745. [CrossRef]

129. Barman, T.S.; Baruah, U.; Saikia, J.K. Effects of potassium as antitranspirant on tea (Camellia sinensis L.) under drought. Two Bud 2011, 58, 70-73.

130. Wei, J.; Li, C.; Li, Y.; Jiang, G.; Cheng, G.; Zheng, Y. Effects of external potassium (K) supply on drought tolerances of two contrastings winter wheat cultivars. PLoS ONE 2013, 8, 69737. [CrossRef] [PubMed]

131. Fayez, K.A.; Bazaid, S.A. Improving drought and salinity tolerance in barley by application of salicylic acid and potassium nitrate. J. Saudi Soc. Agric. Sci. 2014, 3, 45-55. [CrossRef]

132. Almeida, D.M.; Oliveira, M.M.; Saibo, N.J.M. Regulation of $\mathrm{Na}^{+}$and $\mathrm{K}^{+}$homeostasis in plants: Towards improved salt stress tolerance in crop plants. Genet. Mol. Biol. 2017, 40, 326-345. [CrossRef] [PubMed]

133. Shabala, S.; Cuin, T.A. Potassium transport and plant salt tolerance. Physiol. Plant. 2008, 133, 651-669. [CrossRef] [PubMed]

134. Su, Y.; Luo, W.; Lin, W.; Ma, L.; Kabir, M.H. Model of cation transportation mediated by high-affinity potassium transporters (HKTs) in higher plants. Biol. Proced. Online 2015, 17, 1. [CrossRef] [PubMed]

135. Su, L.; Dai, Z.; Li, S.; Xin, H. A novel system for evaluating drought-cold tolerance of grapevines using chlorophyll fluorescence. BMC Plant Biol. 2015, 15, 82. [CrossRef] [PubMed]

136. Shirazi, M.U.; Asraf, M.Y.; Khan, M.A.; Naqvi, M.H. Potassium induced salinity tolerance in wheat (Triticum aestivum L.). Int. J. Environ. Sci. Technol. 2005, 2, 233-236. [CrossRef]

137. Chartzoulakis, K.; Psarras, G.; Vemmos, S.; Loupassaki, M.; Bertaki, M. Response of two olive cultivars to salt stress and potassium supplement. J. Plant Nutr. 2006, 29, 2063-2078. [CrossRef]

138. Umar, S.; Diva, I.; Anjum, N.A.; Iqbal, M.; Ahmad, I.; Pereira, E. Potassium-induced alleviation of salinity stress in Brassica campestris L. Cent. Eur. J. Biol. 2011, 6, 1054-1063. [CrossRef]

139. Abbasi, G.H.; Akhtar, J.; Anwar-Ul-Haq, M.; Ali, S.; Chen, Z.; Malik, W. Exogenous potassium differentially mitigates salt stress in tolerant and sensetive maize hybrids. Pak. J. Bot. 2014, 46, 135-146.

140. Saida, C.; Houria, B.; Mebarek, B. Interactive effects of salinity and potassium on physio-morphological traits of tomato (Lycopersicon esculentum L.). Agric. Biol. J. N. Am. 2014, 5, 135-143.

141. Chakraborty, K.; Bhaduri, D.; Meena, H.N. External potassium $\left(\mathrm{K}^{+}\right)$application improves salinity tolerance by promoting $\mathrm{Na}^{+}$-exclusion, $\mathrm{K}^{+}$-accumulation and osmotic adjustment in contrasting peanut cultivars. Plant Physiol. Biochem. 2016, 103, 143-153. [CrossRef] [PubMed]

142. Amjad, M.; Akhtar, J.; Murtaza, B.; Abbas, G.; Jawad, H. Differential accumulation of potassium results in varied salt-tolerance response in tomato (Solanum lycopersicum L.) cultivars. Hortic. Environ. Biotechnol. 2016, 57, 248-258. [CrossRef]

143. Merwad, A.R.M.A. Efficiency of potassium fertilization and salicylic acid on yield and nutrient accumulation of sugar beet grown on saline soil. Commun. Soil Sci. Plant Anal. 2016, 47, 1184-1192. [CrossRef] 
144. Taffouo, V.D.; Wamba, O.F.; Youmbi, E.; Nono, G.V.; Akoa, A. Growth, yield, water status and ionic distribution response of three bambara groundnut (Vigna subterranea (L.) Verdc.) landraces grown under saline conditions. Int. J. Bot. 2010, 6, 53-58. [CrossRef]

145. Shabala, S.N.; Lew, R.R. Turgor regulation in osmotically stressed Arabidopsis epidermal root cells. Direct support for the role of inorganic ion uptake as revealed by concurrent flux and cell turgor measurements. Plant Physiol. 2002, 129, 290-299. [CrossRef] [PubMed]

146. Flowers, T.J.; Munns, R.; Colmer, T.D. Sodium chloride toxicity and the cellular basis of salt tolerance in halophytes. Ann. Bot. 2015, 115, 419-431. [CrossRef] [PubMed]

147. Shabala, L.; Zhang, J.; Pottosin, I.; Bose, J.; Zhu, M.; Fuglsan, A.T.; Velarde-Buendia, A.; Massart, A.; Hill, C.B.; Roessner, U. Cell-type specific $\mathrm{H}^{+}$-ATPase activity in root tissues enables $\mathrm{K}^{+}$retention and mediates acclimation of barley (Hordeum vulgare L.) to salinity stress. Plant Physiol. 2016, 172, 2445-2458. [CrossRef] [PubMed]

148. Azedo-Silva, J.; Osorio, J.; Fonseca, F.; Correia, M.J. Effects of soil drying and subsequent re-watering on the activity of nitrate reductase in roots and leaves of Helianthus annuus. Funct. Plant Biol. 2004, 31, 611-621. [CrossRef]

149. Dias, A.S.; Lidon, F.C. Bread and durum wheat tolerance under heat stress: A synoptical overview. Emir. J. Food Agric. 2010, 22, 412-436. [CrossRef]

150. Meshah, E.A.E. Effect of irrigation regimes and foliar spraying of potassium on yield, yield components and water use efficiency of wheat in sandy soils. World J. Agric. Sci. 2009, 5, 662-669.

151. Oosterhuis, D.M.; Loka, D.A.; Raper, T.B. Potassium and stress alleviation: Physiological functions and management of cotton. J. Plant Nutr. Soil Sci. 2013, 176, 331-343. [CrossRef]

152. Hasanuzzaman, M.; Fujita, M. Heavy metals in the environment: Current status, toxic effects on plants and possible phytoremediation. In Phyto-technologies: Remediation of Environmental Contaminants; Anjum, N.A., Pereira, M.A., Ahmad, I., Duarte, A.C., Umar, S., Khan, N.A., Eds.; CRC Press: Boca Raton, FL, USA, 2012; pp. 7-73.

153. Chibuike, G.U.; Obiora, S.C. Heavy metal polluted soils: Effect on plants and bioremediation methods. Appl. Environ. Soil Sci. 2014. [CrossRef]

154. Emamverdian, A.; Ding, Y.; Mokhberdoran, F.; Xie, Y. Heavy metal stress and some mechanisms of plant defense response. Sci. World J. 2015. [CrossRef] [PubMed]

155. Siddiqui, M.H.; Al-Whaibi, M.H.; Sakran, A.M.; Basalah, M.O.; Ali, H.M. Effect of calcium and potassium on antioxidant system of Vicia faba L. under cadmium stress. Int. J. Mol. Sci. 2012, 13, 6604-6619. [CrossRef] [PubMed]

156. Song, Z.Z.; Duan, C.L.; Guo, S.L.; Yang, Y.; Feng, Y.F.; Ma, R.J.; Yu, M.L. Potassium contributes to zinc stress tolerance in peach (Prunus persica) seedlings by enhancing photosynthesis and the antioxidant defense system. Genet. Mol. Res. 2015, 14, 8338-8351. [CrossRef] [PubMed]

157. Zaheer, M.M.; Yasin, N.A.; Ahmad, S.R.; Khan, W.U.; Ahmad, A.; Ali, A.; Rehman, S.U. Amelioration of cadmium stress in gladiolus (Gladiolus grandiflora L.) by application of potassium and silicon. J. Plant Nutr. 2017. [CrossRef]

158. Cakmak, I. Tansley Review No. 111 Possible roles of zinc in protecting plant cells from damage by reactive oxygen species. New Phytol. 2000, 146, 185-205. [CrossRef]

159. Choi, S.; Jeong, S.; Jeong, W.; Kwon, S.; Chow, W.; Park, Y.I. Chloroplast Cu/Zn-superoxide dismutase is a highly sensitive site in cucumber leaves chilled in the light. Planta 2002, 216, 315-324. [CrossRef] [PubMed]

160. Lu, T.; Meng, Z.; Zhang, G.; Qi, M.; Sun, Z.; Liu, Y.; Li, T. Sub-high temperature and high light intensity induced irreversible inhibition on photosynthesis system of tomato plant (Solanum lycopersicum L.). Front. Plant Sci. 2017, 8. [CrossRef] [PubMed]

161. Schumann, T.; Paul, S.; Melzer, M.; Dörmann, P.; Jahns, P. Plant growth under natural light conditions provides highly flexible short-term acclimation properties toward high light stress. Front Plant Sci. 2017, 8, 681. [CrossRef] [PubMed]

162. Lichtenthaler, H.K. The 1-deoxy-D-xylulose-5-phosphate pathway of isoprenoid biosynthesis in plants. Annu. Rev. Plant Biol. 1999, 50, 47-65. [CrossRef] [PubMed]

163. Mugnai, S.; Marras, A.M.; Mancuso, S. Effect of hypoxic acclimation on anoxia tolerance in Vitis roots: Response of metabolic activity and $\mathrm{K}^{+}$fluxes. Plant Cell Physiol. 2011, 52, 1107-1116. [CrossRef] [PubMed] 
164. Teakle, N.L.; Bazihizina, N.; Shabala, S.; Colmer, T.D.; Barrett-Lennard, E.G.; Rodrigo-Moreno, A.; Läuchli, A.E. Differential tolerance to combined salinity and $\mathrm{O}_{2}$ deficiency in the halophytic grasses Puccinellia ciliata and Thinopyrum ponticum: The importance of $\mathrm{K}^{+}$retention in roots. Environ. Exp. Bot. 2013, 87, 69-78. [CrossRef]

165. Dwivedi, S.K.; Kumar, S.; Bhakta, N.; Singh, S.K.; Rao, K.K.; Mishra, J.S.; Singh, A.K. Improvement of submergence tolerance in rice through efficient application of potassium under submergence-prone rainfed ecology of Indo-Gangetic Plain. Funct. Plant Biol. 2017, 44, 907-916. [CrossRef]

166. Hasanuzzaman, M.; Hossain, M.A.; da Silva, J.A.T.; Fujita, M. Plant responses and tolerance to abiotic oxidative stress: Antioxidant defense is a key factor. In Crop Stress and Its Management: Perspectives and Strategies; Bandi, V., Shanker, A.K., Shanker, C., Mandapaka, M., Eds.; Springer: Berlin, Germany, 2012; pp. 261-316.

167. Bhattacharjee, S. Sites of generation and physicochemical basis of formation of reactive oxygen species in plant cell. In Reactive Oxygen Species and Antioxidants in Higher Plants; Gupta, S.D., Ed.; CRC Press: New York, NY, USA, 2010; pp. 1-30.

168. Gill, S.S.; Tuteja, N. Reactive oxygen species and antioxidant machinery in abiotic stress tolerance in crop plants. Plant Physiol. Biochem. 2010, 48, 909-930. [CrossRef] [PubMed]

169. Sharma, P.; Jha, A.B.; Dubey, R.S.; Pessarkli, M. Reactive oxygen species, oxidative damage, and antioxidant defense mechanism in plants under stressfull conditions: A review. J. Bot. 2012, 26. [CrossRef]

170. Lemoine, R.; La Camera, S.; Atanassova, R.; Dédaldéchamp, F.; Allario, T.; Pourtau, N.; Bonnemain, J.L.; Laloi, M.; Coutos-Thévenot, P.; Maurousset, L. Source-to-sink transport of sugar and regulation by environmental factors. Front. Plant Sci. 2013, 4, 272. [CrossRef] [PubMed]

171. Griffiths, C.A.; Paul, M.J.; Foyer, C.H. Metabolite transport and associated sugar signalling systems underpinning source/sink interactions. Biochim. Biophys. Acta 2016, 1857, 1715-1725. [CrossRef] [PubMed]

172. Hasanuzzaman, M.; Hossain, M.A.; Fujita, M. Nitric oxide modulates antioxidant defense and the methylglyoxal detoxification system and reduces salinity-induced damage of wheat seedlings. Plant Biotechnol. Rep. 2011, 5, 353-365. [CrossRef]

173. Sangakkara, U.R.; Frehner, M.; Nösberger, J. Effect of soil moisture and potassium fertilizer on shoot water potential, photosynthesis and partitioning of carbon in mungbean and cowpea. J. Agron. Crop Sci. 2000, 185, 201-207. [CrossRef]

174. Milford, G.F.J.; Johnston, A.E. Potassium and Nitrogen Interactions in Crop Production; International Fertiliser Society: York, UK, 2007; p. 615.

175. AbdElgawad, H.; Zinta, G.; Hegab, M.M.; Pandey, R.; Asard, H.; Abuelsoud, W. High salinity induces different oxidative stress and antioxidant responses in maize seedlings organs. Front. Plant Sci. 2016, 7, 276. [CrossRef] [PubMed]

176. Shabala, S. Salinity and programmed cell death: Unravelling mechanisms for ion specific signalling. J. Exp. Bot. 2009, 60, 709-711. [CrossRef] [PubMed]

177. Shirazi, M.U.; Asif, S.M.; Khanzada, M.; Khan, M.A.; Ali, M.; Mumtaz, S.; Yousufzai, M.N.; Saif, M.S. Growth and ion accumulation in some wheat genotypes under $\mathrm{NaCl}$ stress. Pak. J. Biol. Sci. 2001, 4, 388-391.

178. Bar-Tal, A.S.; Sparks, D.L.F. Potassium-salinity interaction in irrigated corn. Irrig. Sci. 2004, 12, $27-35$. [CrossRef]

179. Cha-um, S.; Siringam, K.; Juntawong, N.; Kirdmanee, C. Water relations, pigment stabilization, photosyntheticabilities and growth improvement in salt stressed rice plants treated with exogenous potassium nitrate application. Int. J. Plant Prod. 2010, 4, 187-198.

180. Liang, T.B.; Wang, Z.L.; Wang, R.J.; Liu, L.L.; Shi, C.Y. Effects of potassium humate on ginger root growth and its active oxygen metabolism. Ying Yong Sheng Tai Xue Bao 2007, 18, 813-817. [PubMed]

181. Zheng, Y.; Aijun, J.; Tangyuan, N.; Jialin, X.; Zengjia, L.; Gaoming, J. Potassium nitrate application alleviates sodium chloride stress in winter wheat cultivars differing in salt tolerance. J. Plant Physiol. 2008, 165, 1455-1465. [CrossRef] [PubMed]

182. Jan, A.U.; Hadi, F.; Nawaz, M.A.; Rahman, K. Potassium and zinc increase tolerance to salt stress in wheat (Triticum aestivum L.). Plant Physiol. Biochem. 2017, 116, 139-149. [CrossRef] [PubMed]

183. Kaya, C.; Kirnak, H.; Higgs, D. Enhancement of growth and normal growth parameters by foliar application of potassium and phosphorus in tomato cultivars grown at high $(\mathrm{NaCl})$ salinity. J. Plant Nutr. 2001, 24, 357-367. [CrossRef] 
184. Peuke, A.D.; Jeschke, W.D.; Hartung, W. Flows of elements, ions and abscisic acid in Ricunus communis and site of nitrate reduction under potassium limitation. J. Exp. Bot. 2002, 53, 241-250. [CrossRef] [PubMed]

185. Jiang, M.; Zhang, J. Effect of abscisic acid on active oxygen species, antioxidative defence system and oxidative damage. Plant Cell Physiol. 2001, 42, 1265-1273. [CrossRef] [PubMed]

186. Lin, C.C.; Kao, C.H. Abscisic acid induced changes in cell wall peroxidase activityand hydrogen peroxide level in roots of rice seedlings. Plant Sci. 2001, 160, 323-329. [CrossRef]

187. Tu, B.; Liu, C.; Tian, B.; Zhang, Q.; Liu, X.; Herbert, S.J. Reduced abscisic acid content is responsible for enhanced sucrose accumulation by potassium nutrition in vegetable soybean seeds. J. Plant Res. 2017, 130, 551-558. [CrossRef] [PubMed]

188. Hawkesford, M.; Horst, W.; Kichey, T.; Lambers, H.; Schjoerring, J.; SkrumsagerMoller, I.; White, P. Function of macronutrients. In Marschner's Mineral Nutrition of Higher Plants; Marschner, P., Ed.; Academic Press: London, UK, 2012; pp. 135-189.

189. Mengel, K. Potassium. In Handbook of Plant Nutrition; Barker, A.V., Pilbeam, D.J., Eds.; CRC Press: Boca Raton, FL, USA, 2007; pp. 91-120.

190. Mengel, K. Principles of Plant Nutrition, 5th ed.; Kluwer Academic: Dordrecht, The Netherlands, 2001; pp. 481-509.

191. Berg, W.K.; Cunningham, S.M.; Brouder, S.M.; Joern, B.C.; Johnson, K.D.; Volence, J.J. Influence of phosphorus and potassium on alfalfa yield, taproot $\mathrm{C}$ and $\mathrm{N}$ pools, and transcript levels of key genes after defoliation. Crop Sci. 2009, 49, 974-982. [CrossRef]

192. Prasad, D.; Singh, R.; Singh, A. Management of sheath blight of rice with integrated nutrients. Indian Phytol. 2010, 63, 11-15.

193. Wang, Y.; Wu, W.H. Plant sensing and signaling in response to $\mathrm{K}^{+}$deficiency. Mol. Plant 2010, 3, $280-287$. [CrossRef] [PubMed]

194. Ashley, M.K.; Grant, M.; Grabov, A. Plant responses to potassium deficiencies: A role for potassium transport proteins. J. Exp. Bot. 2006, 57, 425-436. [CrossRef] [PubMed]

195. Armengaud, P.; Sulpice, R.; Miller, A.J.; Stitt, M.; Amtmann, A.; Gibon, Y. Multilevel analysis of primary metabolism provides new insights into the role of potassium nutrition for glycolysis and nitrogen assimilation in Arabidopsis roots. Plant Physiol. 2009, 150, 772-785. [CrossRef] [PubMed]

196. Shin, R.; Schachtman, D.P. Hydrogen peroxide mediates plant root cell response to nutrient deprivation. Proc. Natl. Acad. Sci. USA 2004, 101, 8827-8832. [CrossRef] [PubMed]

197. Wang, X.L.; Yu, H.Q.; Liu, N.; Yi, B.; Cao, M.J. Physiological characteristics of delaying leaf senescence in maize inbred lines tolerant to potassium deficiency. Acta Agron. Sin. 2012, 38, 1672-1679. [CrossRef]

198. Jung, W.J.Y.; Shin, R.; Schachtmana, D.P. Ethylene mediates response and tolerance to potassium deprivation in Arabidopsis. Plant Cell 2009, 21, 607-621. [CrossRef] [PubMed]

199. Hepper Doss, A.; Anand, S.P.; Keerthiga, M. Effect of foliar application of diammonium phosphate (DAP), potash (K) and naphthalene acetic acid (NAA) on growth, yield and some biochemical constituents of Vigna mungo (I.). Wudpecker J. Agric. Res. 2013, 2, 206-208.

200. Kumar, N.; Dawson, J. Effect of different levels of nitrogen, potash and gibberellic acid $\left(\mathrm{GA}_{3}\right)$ application on growth and yield attributes of rice (Oryza sativa L.). Progress. Res. 2013, 8, 197-198.

201. Abd-El-Rhman, I.E.; Attia, M.F. Foliar spray with potassium nitrate and salicylic acid for improving growth, yield and nutrients uptake by olive trees under salinity stress conditions. Int. J. ChemTech Res. 2016, 9, 230-245.

202. Troufflard, S.; Mullen, W.; Larson, T.R.; Graham, I.A.; Crozier, A.; Amtmann, A.; Armengaud, P. Potassium deficiency induces the biosynthesis of oxylipins and glucosinolates in Arabidopsis thaliana. BMC Plant Biol. 2010, 10, 172. [CrossRef] [PubMed]

203. Richards, F.J.; Coleman, R.G. Occurrence of putrescine in potassium-deficient barley. Nature 1952, 170, 479-481. [CrossRef]

204. Liu, K.; Fu, H.; Bei, Q.; Luan, S. Inward potassium channel in guard cells As a target for polyamine regulation of stomatal movements. Plant Physiol. 2000, 124, 1315-1325. [CrossRef] [PubMed]

205. Xu, J.; Li, H.D.; Chen, L.Q.; Wang, Y.; Liu, L.L.; He, L.; Wu, W.H. A protein kinase, interacting with two calcineurin B-like proteins, regulates $\mathrm{K}^{+}$transporter AKT1 in Arabidopsis. Cell 2006, 125, 1347-1360. [CrossRef] [PubMed] 
206. Behera, S.; Long, Y.; Schmitz-Thom, I.; Wang, X.P.; Zhang, C.; Li, H.; Wu, W.H. Two spatially and temporally distinct $\mathrm{Ca}_{2}{ }^{+}$signals convey Arabidopsis thaliana responses to $\mathrm{K}^{+}$deficiency. New Phytol. 2017, 213, 739-750. [CrossRef] [PubMed]

207. Kim, M.J.; Ciani, S.; Schachtman, D.P. A peroxidase contributes to ROS production during Arabidopsis root response to potassium deficiency. Mol. Plant 2010, 3, 420-427. [CrossRef] [PubMed]

208. Demidchik, V. Mechanisms and physiological roles of $\mathrm{K}^{+}$efflux from root cells. J. Plant Physiol. 2014, 171, 696-707. [CrossRef] [PubMed]

209. Schachtman, D.P. The role of ethylene in plant responses to $\mathrm{K}^{+}$deficiency. Front. Plant Sci. 2015, 6. [CrossRef] [PubMed]

210. Chen, Y.; Ma, J.; Miller, A.J.; Luo, B.; Wang, M.; Zhu, Z.; Ouwerkerk, P.B. OsCHX14 is involved in the $\mathrm{K}^{+}$ homeostasis in rice (Oryza sativa) flowers. Plant Cell Physiol. 2016, 57, 1530-1543. [CrossRef] [PubMed]

211. Hu, B.; Wang, W.; Deng, K.; Li, H.; Zhang, Z.; Zhang, L.; Chu, C. MicroRNA399 is involved in multiple nutrient starvation responses in rice. Front. Plant Sci. 2015, 6. [CrossRef] [PubMed]

(C) 2018 by the authors. Licensee MDPI, Basel, Switzerland. This article is an open access article distributed under the terms and conditions of the Creative Commons Attribution (CC BY) license (http:/ / creativecommons.org/licenses/by/4.0/). 